$1-1-2013$

\title{
Scattered and Dissonant: The Clean Air Act, Greenhouse Gases, and Implications for the Oil and Gas Industry
}

\author{
Alex Ritchie \\ University of New Mexico - School of Law
}

Follow this and additional works at: https://digitalrepository.unm.edu/law_facultyscholarship

Part of the Environmental Law Commons, Natural Resources Law Commons, and the Oil, Gas, and Mineral Law Commons

\section{Recommended Citation}

Alex Ritchie, Scattered and Dissonant: The Clean Air Act, Greenhouse Gases, and Implications for the Oil and Gas Industry, 43 Environmental Law 461 (2013).

Available at: https://digitalrepository.unm.edu/law_facultyscholarship/318

This Article is brought to you for free and open access by the UNM School of Law at UNM Digital Repository. It has been accepted for inclusion in Faculty Scholarship by an authorized administrator of UNM Digital Repository. For more information, please contact amywinter@unm.edu, Isloane@salud.unm.edu,sarahrk@unm.edu.

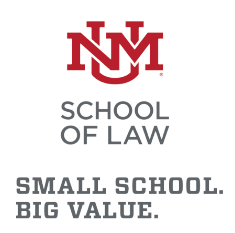

BIG VALUE. 


\title{
SCATTERED AND DISSONANT: THE CLEAN AIR ACT, GREENHOUSE GASES, AND IMPLICATIONS FOR THE OIL AND GAS INDUSTRY
}

\author{
BY
}

\author{
ALEX RITCHIE*
}

In the midst of a domestic oil and gas production revolution, the Environmental Protection Agency (EPA) has constructed a web of findings and regulations to control greenhouse gas ( $G H G$ ) emissions from stationary sources under the auspices of the Clean Air Act. This Article explores the theoretical and practical implications for the oil and gas industry of EPA's CAA GHG regulatory regime that, in light of congressional paralysis, will continue to expand beyond major new and modified oil and gas facilities such as refineries and natural gas processing plants. Future rulemakings directly aimed at the oil and gas industry will likely include lower regulatory thresholds for permitting and control technology requirements, performance based GHG emissions standards for refineries, and amendments to recentlyadopted air emissions performance standards for oil and gas production to address $G H G$. Indirectly, contemplated rules for new and existing power plants may effectively eliminate coal as a substitute for natural gas in the generation of electricity, causing the domestic price of natural gas and electricity to increase amid inevitable liquefied natural gas exports to foreign nations. And if a federal market-based program is ever adopted, GHG reporting requirements indicate that oil and gas companies could be assessed and forced to pass on to consumers the cost of GHG automobile emissions. All of these regulatory programs will eventually sweep in smaller independent oil and gas producers and increase the cost to produce, process, and refine oil and gas.

* Assistant Professor of Law, University of New Mexico School of Law; B.S.B.A. 1993, Georgetown University, J.D. 1999, University of Virginia. Much of the subject of this article was presented by the author and Jacy Rock, Esq. at a conference held on February 28 and March 1, 2013, in Denver, Colorado, sponsored by the Rocky Mountain Mineral Law Foundation entitled "Special Institute on Air Quality Issues Affecting Oil, Gas and Mining Development in the West." The author wishes to thank Jacy Rock, Julie Domike, co-editor of THE CLEAN AIR ACT HANDBOOK (3d ed. 2011), Professors Reed Benson, Eileen Gauna, and Max Minzner, Associate Professor Camille Carey, and Assistant Professors George Bach and Yael Cannon for their thoughtful insights and comments. The author also wishes to thank Zoe Lees and Ernesto Longa for their research assistance. 
I. INTRODUCTION 463

II. REgulation of GHG UNDER THE PREVENTION OF SignifiCANT DETERIORATION Program 466

A. GHG as Air Pollutant and the Path of GHG Regulation under PSD.............466

1. Massachusetts v. EPA. 466

2. The Endangerment Finding, the Tailpipe Rule, the Timing Rule, and the PSD Trigger.

3. The Tailoring Rule: Avoiding the Administrative Train Wreck............470

4. Coalition of Responsible Citizens v. EPA ..........................................472

B. Implications of PSD GHG Regulation for the Oil and Gas Industry.............477

1. Source Categories Brought Into PSD Review Because of GHG

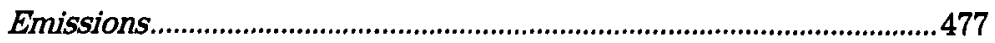

2. Lowering of GHG Emissions Thresholds - Adding Sources..................478

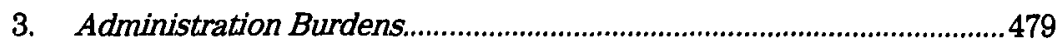

a. Permitting and Review....................................................................479

b. Permit Avoidance ...........................................................................481

c. Best Available Control Technology ...............................................482

i. General Guidance................................................................483

ii. Specific Guidance..................................................................485

d. Potential Streamlining Approaches .................................................486

4. GHG as NAAQS Criteria Pollutant?...................................................489

5. Regulation of Other Pollutants under Varying Thresholds ...................490

III. NEw SOURCE PERFormance STANDARd REgULATION OF GHG ...................................491

A. The Path of New Source Performance Standard (NSPS) Regulation...........491

1. The NSPS Settlement Agreement........................................................ 491

2. Power Plant GHG New Source Performance Standards.......................492

B. Implications of NSPS GHG Regulation for the Oil and Gas Industry ..........494

1. Implications of New and Existing Power Plant NSPS and the

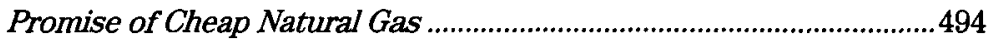

2. Refinery New Source Performance Standards.........................................498

3. Future Regulation of Midstream and Upstream Oil and Gas and

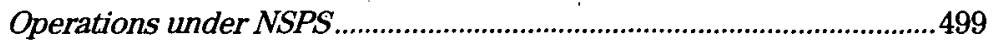

4. Regulation of Existing Sources under NSPS? .....................................500

IV. Federal Market-Based Regulation OF GHG........................................................503

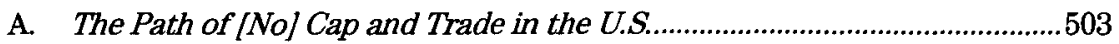

1. Climate Change Legislation................................................................503

2. The Mandatory Greenhouse Gas Reporting Rule ...............................504

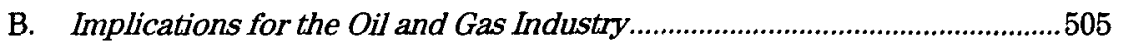

1. Administration of the Reporting Rule ...............................................505

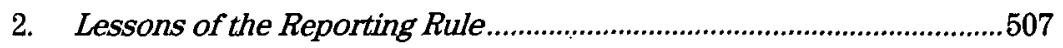

V. STATE MARKET BASEd REgulation OF GHG........................................................509

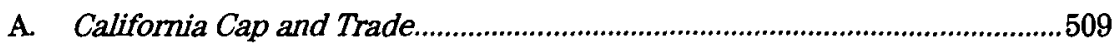

B. Implications for the Oil and Gas Industry ................................................511 
VI. CONCLUSION

\section{INTRODUCTION}

If the predictions of the International Energy Agency (IEA) come to pass, "the U.S. will become the world's top producer of oil by 2020, a net exporter of oil around 2030, and nearly self-sufficient in energy by 2035," all spurred by U.S. domestic oil and gas production, with much of the gains attributable to horizontal drilling and hydraulic fracturing technologies. ${ }^{1}$ The advancement of these technologies to extract natural gas from unconventional shale rock will see production growth from approximately 650 billion cubic meters in 2011 to 800 billion cubic meters in 2035 "putting the United States ahead of Russia as the largest gas producer in the world between 2015 and the end of the 2020 s. $^{2}$

In the midst of this overwhelming revolution in domestic oil and gas production, industry operators face an ever more complex web of regulations to control greenhouse gas (GHG) emissions ${ }^{3}$ that have been promulgated or proposed under the auspices of the Clean Air Act (CAA). ${ }^{4}$ Based on the holding in Massachusetts v. EPA that greenhouse gases are an "air pollutant," the Environmental Protection Agency (EPA) has morphed a statute to control GHGs emitted from motor vehicles into a tailored program to control emissions from new or modified stationary sources that emit or have the potential to emit over thresholds arbitrarily set by EPA. This GHG Prevention of Significant Deterioration (PSD) program now covers refineries and certain natural gas processing and treatment plants and is sure to be expanded to other industry segments.

1 Ronald D. White and Tiffany Hsu, Drilling Our Way to Oil Independence, ALBUQUERQUE JoURNAL, Nov. 18, 2012, at C6 (as reprinted from the L.A. TIMES) (citing INT'L ENERGY AgENCY, WORLD ENERGY OUTLOOK 2012 (Nov. 2012) [hereinafter IEA REPORT]). The IEA REPORT also states that by 2035 , energy related carbon dioxide emissions will increase, causing an increase in long-term average global temperatures. This will occur as the global energy demand of China rises $60 \%$, the global energy demand of India doubles, and the energy demand in developed countries rises overall by only 3\%. Id. at 49. Cf. FOOD AND WATER WATCH, U.S. ENERGY INSECURITY: Why FraCKING FOR OIL AND NATURAL GAS Is a FALSE SOLUTION 9 (2012), available at http://documents.foodandwaterwatch.org/doc/USEnergyInsecurity.pdf [hereinafter FOOD AND WATER WATCH] (arguing that the IEA REPORT conflates production numbers by assuming "that the industry will get its wish of completely unrestricted access throughout Alaska, throughout the lower 48 states and all along the U.S. coastline").

2 IEA REPORT, supra note 1 , at 136.

3 GHG is used herein consistent with the definition in the "Tailoring Rule" as the aggregate of the six GHGs carbon dioxide $\left(\mathrm{CO}_{2}\right)$, methane $\left(\mathrm{CH}_{4}\right)$, nitrous oxide $\left(\mathrm{N}_{2} \mathrm{O}\right)$, hydrofluorocarbons (HFCs), perfluorocarbons (PFCs), and sulfur hexafluoride ( $\mathrm{SF}_{\ell}$ ). Prevention of Significant Deterioration and Title V Greenhouse Gas Tailoring Rule, 75 Fed. Reg. 31,514, 31,518 (June 3, 2010) (codified at 40 C.F.R. pts. 51, 52, 70, 71) [hereinafter Tailoring Rule].

442 U.S.C. $\$ \S 7401-7671 q(2006)$.

5549 U.S. 497 (2007).

6 Id. at 528-29. 
In Coalition for Responsible Regulation, Inc. v. EPA, industry and various states challenged EPA's Prevention of Significant Deterioration program in the D.C. Circuit Court of Appeals to no avail. ${ }^{8}$ Notwithstanding that the special solicitude of the states was in part the basis for standing in Massachusetts, ${ }^{\ominus}$ no such solicitude was provided the state petitioners in Coalition. Unless the Supreme Court grants certiorari and reverses the D.C. Circuit, the arbitrary thresholds established by EPA to regulate GHG emissions for major sources may never receive a substantive review from the federal courts.

President Obama, spurred by environmental groups, is currently focused on the coal-fired power plant industry as EPA moves to promulgate New Source Performance Standards for new-and then-existing electric utility generating units. ${ }^{10}$ Eventually, however, the focus of environmental groups will turn toward an oil and gas industry that such groups describe as "dirty, dangerous and run amok."11

Actions by EPA to control GHG emissions through the CAA are not without critics unconnected to industry. Many commentators believe that, because carbon dioxide is not a toxic pollutant and does not cause direct damage to human health, the CAA is a poor fit for the regulation of GHGs. ${ }^{12}$ Although opposed by most in the oil and gas industry, a federal incentivebased program such as cap-and-trade or a carbon tax could create a much more flexible, cost-effective solution to climate change than ill-fitting provisions of the $\mathrm{CAA} .{ }^{13}$ Independent oil and gas producers especially may

7684 F.3d 102 (D.C. Cir. 2012) (per curiam), en banc rehearing denied, 2012 WL 6621785; 2012 WL 6681996 (D.C. Cir. 2012).

8 Id. at 113 (upholding EPA's conclusion that GHGs endanger the public health and welfare and finding that plaintiffs lacked standing to challenge EPA's rules relating to GHGs under its PSD program).

9 Massachusetts, 549 U.S. at 520.

10 See Keith Johnson, Tom Fowler, \& Cassandra Sweet, President Details Sweeping Climate. Policies, WALL ST. J., June 26, 2013, at A1.

11 Kevin Begos, Gas Drilling Presents Obama With Historic Choices, Assoclated PREsS (Nov. 17, 2012), http://bigstory.ap.org/article/gas-drilling-presents-obama-historic-choices; see generally FOOD AND WATER WATCH, supra note 1 (providing an example of environmental group already turning its attention to oil and gas).

12 See, e.g., Arnold W. Reitze, Jr., The Intersection of Climate Change and Clean Air Act Stationary Source Programs, 43 ARIZ. ST. L.J. 901, 923, 941 (2011) (arguing that the CAA is a poor vehicle for controlling the release of $\mathrm{CO}_{2}$ because it is not toxic at the concentrations found in the environment and does not cause direct damage to human health).

13 See, e.g., Robert B: Moreno and Peter Zalzal, Greenhouse Gas Dissonance: The History of 'EPA's Regulations and the Incongruity of Recent Legal Challenges, 30 UCLA J. ENVTL. L. \& POL'Y 121, 155-56 (2012) (asserting that although New Source Performance Standards may allow for cap-and-trade, legislation is better suited to the task); DALLAS BURTRAw, ART FRAAS, \& NATHAN RICHARDSON, GREENHOUSE GAS REgULATION UNDER THE ClEAN AIR ACT: A GUIDE FOR ECONOMISTS 20 (2011), available at http://www.rff.org/RFF/Documents/RFF-DP-11-08.pdf (providing that, although New Source Performance Standards may allow for limited emission trading, economywide, "incentive-based mechanisms are widely thought to do a better job than prescriptive regulation in promoting innovation in production processes, with this advantage growing over time."); Peter Behr, Wild Cards Lurk in the Speedy Switch to Gas-fired Power Generation, E\&E PUBLISHING, LLC (Feb. 25, 2013), available at http://www.eenews.net/energywire/stories/1059 
be unable to afford costly regulatory controls, but may have the ability to better manage costs through a market-based system by sharing the GHG burden with large integrated companies. ${ }^{14}$

While a number of comprehensive climate change bills have been proposed since President Barack Obama took office, they have all suffered at the hand of political gridlock. ${ }^{15}$ Congressional legislators that support action on climate change have simply come to view the exercise by EPA of authority under the CAA to regulate $\mathrm{CO}_{2}$ as an expedient means to avoid the political ramifications of climate change legislation. ${ }^{16}$

In the meantime, California has begun implementation of its cap-andtrade program, providing a convenient testing ground for potential future federal climate change legislation. ${ }^{17}$ The California program will begin slowly at first, but time will tell whether California will remain a competitive marketplace for oil and gas refiners, processors, and producers.

This Article explores the practical and theoretical implications for the oil and gas industry of EPA's GHG regulatory regime and its inevitable expansion. The decision in Coalition opens the door for EPA to lower thresholds for permitting and control technology to apply to smaller independent producers; to adopt GHG performance standards for refineries; and to eventually expand GHG performance standards to well-site oil and natural gas drilling and completion operations. While new GHG regulations increase the cost of natural gas production, proposed GHG power plant rules may ironically intensify the demand for natural gas at the same time that the U.S. begins its transformation into a liquefied natural gas exporter. These pressures on demand may increase the price of natural gas, a fuel

976784 ("Particularly in the U.S., we all believe at the end of the day command and control does not work...") (quoting Arshad Mansoor, Senior Vice President for Research at the Electric Power Research Institute).

14 See Winthrop Quigley, Taking Aim at Oil and Gas, ALBUQUERQUE JouRNAL, Nov. 28, 2011, at Business Outlook, 1 ("The independent [oil and gas producers] are much more financially vulnerable than most people realize" as compared to large producers); cf. The Distributional Consequences of a Cap-and-Trade Program for CO2 Emissions: Hearing Before the $H$. Subcomm. on Income Sec. and Family Support Comm. on Ways and Means, 111th Cong. 5-7 (2009) (statement of Terry M. Dinan, Senior Advisor) (explaining that, relative to higher income households, low income households will be more heavily impacted by cap-and-trade due to lessoned ability to absorb increased price of goods resulting from GHG regulation).

15 For example, the Center for Climate and Energy Solutions explained that "[r]eflecting an anti-regulatory mood on Capitol Hill, there were nearly as many proposals in the 112th Congress to block efforts to curb carbon emissions as proposals to strengthen them. And, reflecting the general state of gridlock in Congress, virtually none of the bills proposed were enacted." Legislation in the 112th Congress Related to Global Climate Change, http://www.c2es. org/federal/congress/112 (last visited July 21, 2013).

16 See George F. Allen \& Marlo Lewis, Finding the Proper Forum for Regulation of U.S. Greenhouse Gas Emissions: The Legal and Economic Implications of Massachusetts v. EPA, 44 U. RICH. L. REv. 919, 935 (2009-10).

17 See generally Matthew Visick, Note, If Not Now, When? The California Global Warming Solutions Act of 2006: California's Final Steps Toward Comprehensive Mandatory Greenhouse Gas Regulation, 13 Hastings W.-NW. J. EnvTL. L. \& POL'Y 249 (2007) (providing background on California's cap-and-trade bill). 
currently viewed as a cheap alternative to coal. Further, should Congress actually adopt a market-based system, the existing GHG reporting program indicates that oil refiners might be made to account for both facility emissions and the emissions of motor vehicles that combust their refined products, forcing refiners to pass such costs to consumers in the price of gasoline at the pump.

Part II of this paper begins with a discussion of the origin of the PSD program as applied to GHGs and its implications for the oil and gas industry, including source categories subject to the rule, administrative burdens, and implications for future regulation. Part III addresses New Source Performance Standards proposed for electric utility generating units, how those standards may affect the oil and gas industry, and how those standards likely will lead to similar regulation of oil and gas operations. Part IV explains federal legislative efforts to regulate climate change, the extensive federal reporting and verification system already in place, and the lessons of this reporting system for the oil and gas industry. Part V focuses on the new California cap-and-trade system and its application to the oil and gas industry.

\section{REgULATION OF GHG UNDER THE PREVENTION OF SIGNIFICANT DETERIORATION PROGRAM}

\section{A. GHG as Air Pollutant and the Path of GHG Regulation under PSD}

\section{Massachusetts v. EPA}

The path of GHG regulation under the CAA began in 1999, when a group of private organizations filed a rulemaking petition asking EPA to regulate GHG emissions from new motor vehicles. ${ }^{18}$ The petitioners marched into battle armed with CAA section 202(a)(1), which provides that the EPA Administrator "shall" regulate emissions of any air pollutant from new motor vehicles, "which in his judgment cause, or contribute to, air pollution which" may reasonably be anticipated to endanger public health or welfare. ${ }^{n 18}$

EPA denied the rulemaking petition in $2003,{ }^{20}$ relying on an unrebutted report by the National Research Council opining that while evidence points to a warming of global surface air temperatures, uncertainties in understanding natural variability in temperatures meant that an unequivocal link between the buildup of GHGs in the atmosphere and observed climate changes could not be established. ${ }^{21}$ EPA concluded in denying the petition

18 See Notice, Request for Comment, Control of Emissions from New and In-use Highway. Vehicles and Engines, 66 Fed. Reg. 7,486, 7,486-87 (Jan. 23, 2001).

1942 U.S.C. $\$ 7521(\mathrm{a})(1)(2006)$.

20 Notice of Denial of Petition for Rulemaking, Control of Emissions From New Highway Vehicles and Engines, 68 Fed. Reg. 52,922 (Sept. 8, 2003).

21 See $i d$. at 52,930 (discussing NaT'L RESEARCH CounciL, ClmMate Change ScIence: AN ANALYSIS OF SOME KEY QUESTIONS (2001)). 
that 1) the CAA did not authorize EPA to issue mandatory regulations to address global climate change, ${ }^{22}$ and 2) even if EPA had such authority, it would be unwise to do so at that time. ${ }^{23}$

Undeterred, the petitioners sought review of EPA's petition denial by the D.C. Circuit Court of Appeals, joined by Massachusetts and other state and local governments. ${ }^{24}$ In a 2-1 decision, the Court denied the petition, holding that EPA's decision to forego rulemaking of GHG emissions was not unreasonable until more was understood about the causes, extent, and significance of climate change. ${ }^{25}$ One year later, the Supreme Court in the seminal case of Massachusetts v. EPA $A^{23}$ reversed the D.C. Circuit, holding in a 5-4 decision that EPA failed to offer a reasoned explanation for its refusal to decide whether GHGs caused or contributed to climate change. ${ }^{27}$

Writing for the majority, Justice John Paul Stevens referred to the broad CAA section 202(a)(1) definition of "air pollutant" as including "any air pollution agent or combination of such agents, including any physical, chemical ... substance or matter which is emitted into or otherwise enters the ambient air. ..."28 Having concluded that GHG was an air pollutant, the majority then concluded that the EPA Administrator's only discretion related to his "judgment" about whether GHG emissions "cause, or contribute to, air pollution which may reasonably be anticipated to endanger public health or welfare." ${ }^{28}$

According to the majority, the reasons offered by EPA not to regulate GHG emissions were impermissible policy considerations, not based on scientific judgment. ${ }^{30}$ Therefore, EPA's refusal to regulate GHG emissions from motor vehicles was arbitrary, capricious, or otherwise not in

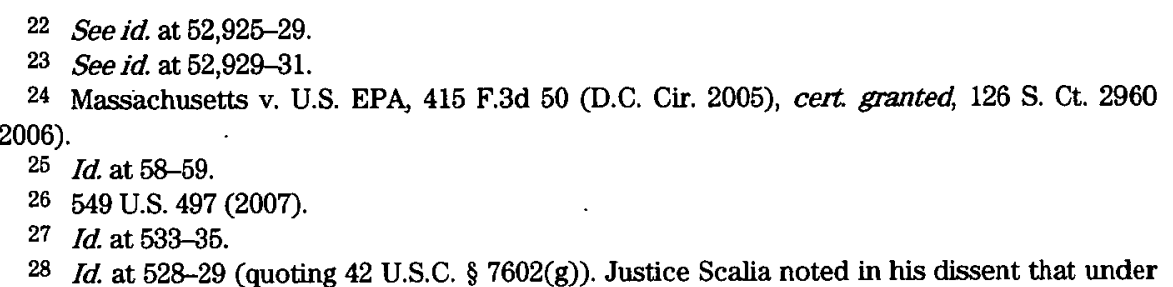
the CAA section $302(\mathrm{~g})$, use of the word "including" in the definition of "air pollutant" means that to constitute an "air pollutant" a substance must not only be "any physical, chemical... substance or matter which is emitted into or otherwise enter the ambient air," but must also be an "air pollution agent or a combination of such agents" and that EPA itself argued that regulating the concentration of a substance that is polluting the air, including the ambient air under national ambient air quality standards, is much different than regulating GHGs in the upper reaches of the atmosphere. Id. at 557-59.

29 Id. at 532-33. As noted by Justice Scalia in his dissent, while the statute annunciates the standard for making such a judgment, the statute says nothing about the reasons EPA might give to defer such a judgment. Id. at 552 .

30 Id. at 533-34. The Court specifically stated: "If, the scientific uncertainty is so profound that it precludes EPA from making a reasoned judgment as to whether [GHGs] contribute to global warming, EPA must say so." Id. at 534. Justice Scalia argues in his dissent that the statements made by EPA in its denial of the petitioner's petition for rulemaking say just that. Id. at $553-55$. 
accordance with law. ${ }^{31}$ In contrast, Justice Antonin Scalia, in a dissent joined by Chief Justice John Roberts, Justice Clarence Thomas, and Justice Samuel Alito, believed the liberal majority simply substituted its own desired outcome for the reasoned judgment of EPA in what should have been a straight-forward administrative law case. ${ }^{32}$

\section{The Endangerment Finding, the Tailpipe Rule, the Timing Rule, and the PSD Trigger}

What came next was a flurry of rulemakings and EPA findings that worked together in an intricate web to transform the Massachusetts air pollutant finding as pertains to motor vehicle GHG emissions into the regulation of all major sources that emit GHGs above arbitrary thresholds set by EPA under its PSD program.

As background, the Prevention of Significant Deterioration program is but one part of the CAA New Source Review Program. The New Source Review Program is designed to achieve national ambient air quality standards (NAAQS) for stationary sources of pollutants through three programs: 1) the Prevention of Significant Deterioration program under CAA Title I, Part C, that applies to major sources of emissions in areas that are in attainment (i.e., are meeting) or are unclassified for NAAQS concentration limits; ${ }^{33}$ 2) the nonattainment New Source Review Program under CAA Title I, Part D, that applies to major sources of emissions in areas that are not in attainment of NAAQS concentration limits; ${ }^{34}$ and 3 ) the individual state "minor new source review programs" for non-major sources of emissions.

The battle for the regulation of GHGs under the Prevention of Significant Deterioration program actually began when, in light of Massachusetts, environmental groups challenged the issuance of a permit to construct a new electric generating unit in Bonanza, Utah. ${ }^{36}$ Faced with that challenge, on December 18, 2008, Bush Administration EPA Administrator Stephen L. Johnson issued a memorandum (the Johnson Memo) to address the question of when EPA would begin to regulate GHGs under the Prevention of Significant Deterioration program. ${ }^{37}$ Administrator Johnson concluded in the Johnson Memo that the language "subject to regulation under this [Act]," as used in CAA sections 165(a)(4) and 169, and "regulated

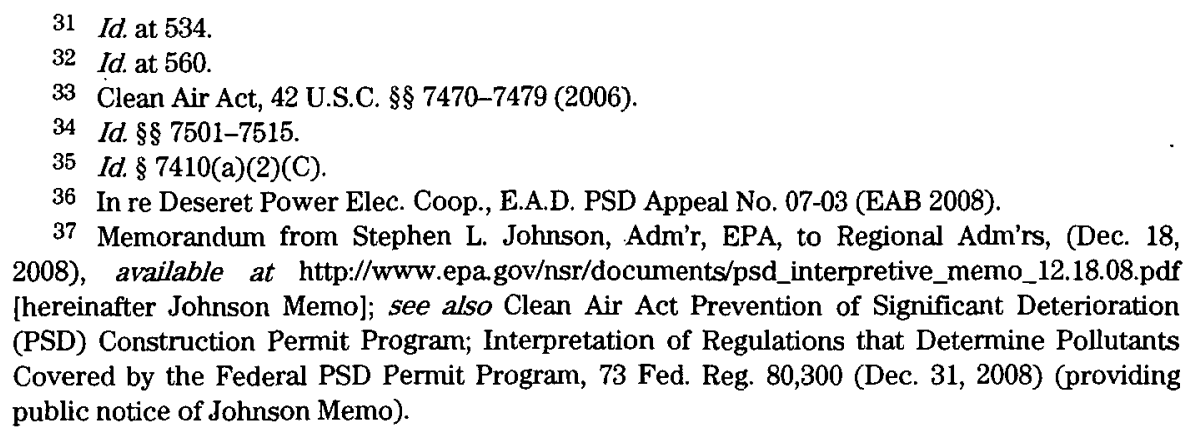
[hereinafter Johnson Memo]; see also Clean Air Act Prevention of Significant Deterioration (PSD) Construction Permit Program; Interpretation of Regulations that Determine Pollutants Covered by the Federal PSD Permit Program, 73 Fed. Reg. 80,300 (Dec. 31, 2008) (providing public notice of Johnson Memo). 
NSR pollutant," as used in the Prevention of Significant Deterioration regulations, required the permitting, not only of NAAQS pollutants, but also any other air pollutant that is subject to another provision of the CAA or underlying regulations that requires the actual control of the pollutant. ${ }^{38}$ In other words, Prevention of Significant Deterioration required the regulation of GHGs when EPA: 1) made the decision that GHG emissions endangered health and welfare under CAA section 202(a)(1);2) adopted a regulation to control those emissions from motor vehicles; and 3) actually began to control those emissions. ${ }^{39}$

Regarding the first element, whether GHGs endangered health and welfare, on December 7, 2009, EPA Administrator Lisa Jackson exercised her "judgment," signing two findings: 1) the "endangerment" finding that GHGs "in the atmosphere threatens the public health and welfare of current and future generations"; and 2) the "Cause or Contribute Finding" that emissions from new motor vehicles "contribute to the greenhouse gas pollution which threatens public health and welfare." In issuing the findings, EPA relied on reports issued by the Intergovernmental Panel on Climate Change, the U.S. Global Climate Research Program, and the National Research Council. ${ }^{41}$

As to the third element in the Johnson Memo, that Prevention of Significant Deterioration would take effect upon the actual control of emissions, EPA received a petition for reconsideration of the "actual control" standard from the Sierra Club and fourteen other organizations, demanding that the term "regulated NSR pollutant" include not only pollutants subject to control, but also pollutants subject to monitoring and reporting requirements. ${ }^{42}$ In response to that petition, on April 2, 2010, EPA issued its final action on reconsideration of its interpretation in the Johnson Memo (the Timing Rule), concluding that the "actual control" standard was appropriate, and further concluding that Prevention of Significant

38 Johnson Memo, supra note 37, at 1 (emphasis added). As the Court in Coalition points out, EPA has defined "major stationary sources" to include sources that emit "any air pollutant regulated under the [CAA]" in rules promulgated in 1978, 1980, and 2002.684 F.3d at 129 (quoting Requirements for Preparation, Adoption; and Submittal of Implementation Plans, Prevention of Significant Air Quality Deterioration, 43 Fed. Reg. 26,380, 26,382 (June 19, 1978)); see also Requirements for Preparation, Adoption, and Submittal of Implementation Plans, Approval and Promulgation of Implementation Plans, 45 Fed. Reg. 52,676, 52,711 (Aug. 7, 1980); see also Prevention of Significant Deterioration and Nonattainment New Source Review, 67 Fed. Reg. 80,186, 80,239-40, 80,264 (Dec. 31, 2002).

39 Id. at 18.

40 Endangerment and Cause or Contribute Findings for Greenhouse Gases under Section 202(a) of the Clean Air Act, 74 Fed. Reg. 66, 496 (Dec. 15, 2009) [hereinafter Endangerment Finding].

41 Coalition, 684 F.3d at 119.

42 See Letter from Lisa P. Jackson, Adm'r, EPA, to David Bookbinder, Chief Climate Counsel, Sierra Club (Feb. 17, 2009), available at http:/www.epa.gov/NSR/documents/2009021 7LPJlettertosierraclub.pdf. 
Deterioration would not apply until a regulatory requirement to control emissions "takes effect."

As to the second element in the Johnson Memo, the actual adoption of a regulation to control GHG emissions from motor vehicles, a little more than a month after EPA issued its Timing Rule, EPA issued its final rule (the Tailpipe Rule) that set GHG emissions standards for 2012-2016 model year cars and light trucks in a joint rulemaking with the National Highway Traffic Safety Administration (NHTSA). ${ }^{44}$ Because the Tailpipe Rule would "take effect" on January $2,2011,{ }^{45}$ based on the Timing Rule the regulation of GHGs under the Prevention of Significant Deterioration program also would take effect on January $2,2011 .^{46}$

\section{The Tailoring Rule: Avoiding the Administrative Train, Wreck}

Now that EPA had committed itself to regulate GHGs under the Prevention of Significant Deterioration program, it was faced with the challenge of avoiding the express statutory thresholds set out in the CAA lest it overwhelm the entire permitting system and face serious political backlash. Prevention of Significant Deterioration applies to the construction of new major stationary sources and to major modifications of existing sources that will emit or that have the potential to emit amounts of a "regulated NSR pollutant" in excess of specified major source thresholds. ${ }^{47}$ The major source threshold is 100 tons per year for certain listed sources that include oil and gas industry petroleum refineries, sulfur recovery plants, and petroleum storage and transfer units with a total storage capacity exceeding 300,000 barrels. $^{48}$ The threshold is 250 tons per year for other stationary sources. ${ }^{49}$

To avoid the administrative "train wreck" ${ }^{\text {"50 }}$ that might result from regulation of GHGs under the 100 tons per year and 250 tons per year

43 Reconsideration of Interpretation of Regulations That Determine Pollutants Covered by Clean Air Act Permitting Programs (Final Rule), 75 Fed. Reg. 17,003-04 (Apr. 2, 2010).

44 Light-Duty Vehicle Greenhouse Gas Emission Standards and Corporate Average Fuel Economy Standards (Final Rule), 75 Fed. Reg. 25,324 (May 7, 2010). EPA and NHTSA subsequently adopted GHG emission standards for model years 2017-2025 and for medium and heavy-duty vehicles, covering model years 2014-2018. 2017 and Later Model Year Light-Duty Vehicle Greenhouse Gas Emissions and Corporate Average Fuel Economy Standards, 77 Fed. Reg. 62,624 (Oct. 15, 2012); see also Michael B. Gerrard, D.C. Circuit Clears Path for GHG Rules, But Politics Remain, 44 A.B.A. SEC. ENV'T, ENERgy \& RES., 1, 2, 4 (2012).

45 See Tailoring Rule, supra note 3, at 75 Fed. Reg. at 31,516.

46 Reconsideration of Interpretation of Regulations That Determine Pollutants Covered by Clean Air Act Permitting Programs, 75 Fed. Reg. 17,004, 17,004 (Apr. 2, 2010).

47 See 42 U.S.C. \$ 7475(a) (2006); see generally CLEAN AIR ACT HANDBOOK 125-200 (Julie R. Domike \& Alec C. Zacaroli, eds., 3d ed. 2011).

4842 U.S.C. $\$ 7479$ (1) (2006) (defining "major emitting facility").

49 Id.

50 See Letter from Kyle Isakower, Dir. Of Policy Analysis, Am. Petroleum Inst., to EPA 5 (Dec. 21, 2009) available at http:/www.whitehouse.gov/sites/default/files/omb/assets/oira_2060/ 2060_2127_03232010-4.pdf (describing the result of regulating GHGs without tailoring as the "administrative train wreck"). 
thresholds expressly set forth in CAA section $165{ }^{51}$ EPA adopted the "Tailoring Rule," magically increasing the statutory thresholds and then lowering those thresholds over time. Without the Tailoring Rule, EPA estimated that the number of major sources of GHG emissions would approximate six million and that permitting authorities would face approximately $\$ 1.5$ billion in additional Prevention of Significant Deterioration permitting costs each year, ${ }^{62}$ representing an 130 times increase in New Source Review permitting burden hours. ${ }^{53}$

The Tailoring Rule provides for a "one-step-at-a-time" multi-step process of gradually reducing the initial 100,000 tons per year $\mathrm{CO}_{2} \mathrm{e}^{54}$ threshold set by EPA based on EPA's legal rationales of "administrative necessity" and to avoid the "absurd results" that would result from a 100/250 tons per year threshold. ${ }^{55}$ To date, EPA has completed three such "steps":

51 See Tailoring Rule, supra note 3, at 31,514 (stating "[t]his rulemaking is necessary because without it PSD and title V requirements would apply, as of January 2, 2011, at the 100 or 250 tons per year (tpy) levels provided under the CAA, greatly increasing the number of required permits, imposing undue costs on small sources, overwhelming the resources of permitting authorities, and severely impairing the functioning of the programs.").

52 Id. at $31,536,31,539$.

53 Id. at $31,539-40$.

$54{ }^{~} \mathrm{CO}_{2} \mathrm{e}$ " is the aggregate of the carbon-dioxide equivalents calculated for each of the six gases that comprise GHG. Id. at 31,606 (codified at 40 C.F.R. $\$ 51.166(\mathrm{~b})(48)$ (ii)).

55 In Chevron U.S.A. Inc. v. Natural Res. Def. Council, Inc. 467 U.S. 837 (1984), the Supreme Court set out a two-step process for reviewing the interpretation by an agency of a statute administered by that agency. Under the first step, "[i]f the intent of Congress is clear, that is the end of the matter; for the court, as well as the agency, must give effect to the unambiguously expressed intent of Congress." Id. at 842-43. Under the second step, "if the statute is silent or ambiguous with respect to the specific issue, the question for the court is whether the agency's answer is based on a permissible construction of the statute." Id. at 843. EPA in its adopting release of the Tailoring Rule was faced with the challenge of "giving effect to the unambiguously expressed intent of Congress" under Cherron in enacting statutory thresholds expressly set out in CAA $\S 165$ so as not to sweep into the regulation dry cleaners, pizza parlors, and even some residences. First, EPA relied on the "absurd results" doctrine, arguing that a literal application of the threshold would be inconsistent with congressional intent and undermine congressional purpose for the PSD program, using case law to support the proposition that "the literal meaning of a statutory provision is not conclusive "in the "rare cases [in which] the literal application of a statute will produce a result demonstrably at odds with the intentions of the drafters..." Tailoring Rule, supra note 3, at 31,542 (citing United States v. Ron Pair Enter., 489 U.S. 235, 242 (1989)). EPA then cited Alabama Power v. Costle, 636 F.2d 323 (D.C. Cir. 1980), and New York v. EPA, 443 F.3d 880, 884, 888 (D.C. Cir. 2006), for the proposition that "an administrative agency may, under the appropriate circumstances, in effect revise statutory requirements that the agency demonstrates are impossible to administer so that they are administrable," id. at $31,543-44$, notwithstanding that the doctrine has only been applied to federal agencies, and PSD is administered by state and local agencies. Id. at 31,544. Finally, EPA cited Massachusetts v. EPA, 549 U.S. 497, 524 (2007), for a concept originating in United States Brewers Ass'n., Inc. v. U.S. Envtl. Prot. Agency, 600 F.2d 974, 982 (D.C. Cir. 1979), that agencies may implement regulatory programs over time in a phased-approach. Id. at 31,544 . Ultimately, the viability of these theories depends on whether a court applying Chevron would agree with EPA that Congress intended for EPA to rewrite the express thresholds in the statute under these circumstances. Because the court in Coalition never reached the substantive merits of EPA's legal arguments, avoiding the merits based on standing doctrines, a court has not yet opined on EPA's theoretical justifications. 
- Under Step 1, as of January 2, 2011, Prevention of Significant Deterioration began to apply to GHG emissions from "anyway" sources (i.e., sources that were already major sources for other pollutants) that undertake a modification resulting in an increase of at least 75,000 tons per year of $\mathrm{CO}_{2} \mathrm{e}$; and Title V (which covers requirements in facility-wide operating permits) began to apply to GHGs from sources already subject to Title V due to their emissions of other pollutants. ${ }^{56}$

- Under Step 2, beginning on July 1, 2011, sources became subject to Prevention of Significant Deterioration based on their emissions 1) for newly constructed sources that emit or have the potential to emit at least 100,000 tons per year of $\mathrm{CO}_{2} \mathrm{e}$, or 2) for existing sources that emit or have the potential to emit at least 100,000 tons per year of $\mathrm{CO}_{2} \mathrm{e}$ and make a modification resulting in an emissions increase of at least 75,000 tons per year of $\mathrm{CO}_{2} \mathrm{e}$; and Title $\mathrm{V}$ began to apply for GHGs to both existing and new sources that became subject to Title $\mathrm{V}$ on account of their GHG emissions if they emit 100,000 tons per year of $\mathrm{CO}_{2} \mathrm{e}^{57}$

- EPA completed Step 3 effective July 1, 2012, determining not to lower the $100,000 / 75,000$ tons per year $\mathrm{CO}_{2}$ e applicability threshold levels. $^{58}$

As far as additional sources and additional steps, EPA stated that Prevention of Significant Deterioration and Title V requirements would not apply to sources of GHGs below a 50,000 tons per year $\mathrm{CO}_{2} \mathrm{e}$ threshold, at least until April 2016, when EPA would issue another round of rulemaking. ${ }^{69}$ To the knowledge of the author, EPA has not yet hinted at where it plans to take the permitting thresholds by April 2016.

\section{Coalition of Responsible Citizens v. EPA}

Industry groups, environmental groups, and states filed more than seventy lawsuits challenging or supporting at least one of the Endangerment Finding, the Tailpipe Rule, and the Timing and Tailoring Rules, ${ }^{60}$ including

5640 C.F.R. $\S 51.166(\mathrm{~b})(48)$ (iv) (2012); Id. § 52.21(b)(49)(iv) (2012).

57 Id. $\$ 51.166(\mathrm{~b})(48)(\mathrm{iv})-(49)$ (v) (2012).

58 Prevention of Significant Deterioration and Title V Greenhouse Gas Tailoring Rule Step 3 and GHG Plantwide Applicability Limits, 77 Fed. Reg. 41,051, 41,055 (July 12, 2012) (to be codified at 40 C.F.R. pt. 52) [hereinafter GHG PSD Step 3 Rulemaking].

5940 C.F.R. $\$ 70.12$ (b) (2012).

60 Challenges to the Endangerment Finding were consolidated as Coal. for Responsible Regulation, Inc. v. EPA. Order at 1, Coal. for Responsible Regulation, Inc. v. EPA, 684 F.3d 102 (D.C. Cir. 2010) (No. 09-1322). Challenges to the Triggering Interpretation and the Tailoring Rule were consolidated as Coal. for Responsible Regulation, Inc. v. EPA. Order at 1, Coal. for Responsible Regulation, Inc. v. EPA, 2012 WL 6621785 (D.C. Cir. 2010) (No. 10-1073). Challenges to the Tailpipe Rule were consolidated as Coal. for Responsible Regulation, Inc. v. EPA. Order at 1, Coal. for Responsible Regulation, Inc. v. EPA, 684 F.3d 102 , (D.C. Cir. 2010) (No. 10-1092). 
thirty-seven states that either directly filed lawsuits or requested to intervene in support of or against at least one of the four actions. ${ }^{61}$ On June 26, 2012, the D.C. Circuit Court of Appeals issued its per curiam opinion in Coalition for Responsible Regulation, Inc. V. EPA, ${ }^{62}$ addressing the consolidated challenges and denying all petitions for review of the complex GHG regulatory structure constructed by EPA after Massachusetts.

The petitioners argued that EPA improperly restricted its judgment as to the Endangerment Finding to a science-based interpretation that did not consider policy and regulatory consequences. ${ }^{63}$ In response, the court determined that the Supreme Court had already decided in Massachusetts that EPA had the authority to regulate GHGs and that neither policy considerations nor regulatory consequences should be considered, "even if the degree of regulation triggered might at a later stage be characterized as 'absurd." ${ }^{64}$ In addressing the scientific basis for the Endangerment Finding, the court gave "an extreme degree of deference to the agency when EPA evaluates scientific data within its technical expertise," ${ }^{25}$ finding that the scientific record relied upon by EPA was substantial. ${ }^{66}$

The petitioners also attacked the Tailpipe Rule, not based on the substance of the rule itself, but on the failure of EPA to consider the cost of the Prevention of Significant Deterioration GHG program when adopting the Tailpipe Rule to regulate vehicle emissions. ${ }^{67}$ Compliance costs of Prevention of Significant Deterioration GHG regulation were never considered by EPA based on the rationale that the regulation of GHGs under Prevention of Significant Deterioration was automatic. ${ }^{68}$ The court agreed with EPA, holding that a consideration of costs was unnecessary given the

See also Caroline Cecot, Note: Blowing Hot Air; An Analysis of State Involvement in Greenhouse Gas Litigation, 65 VAND. L. REv. 189, 190-91 (2012).

61 See, Cecot, supra note 60 (arguing that the decisions of states to join the litigation strongly correlated with political affiliations and bore little relationship to public opinion or the costs and benefits of addressing climate change).

62684 F.3d 102 (D.C. Cir. 2012), en banc reh denied, 2012 WL 6621785; 2012 WL 6681996

(D.C. Cir 2012).

63 Id. at 117.

64 Id. at 119.

65 Id. at 120 (quoting Am. Farm Bureau Fed'n v. EPA, 559 F.2d 512, 519 (D.C. Cir. 2009) (internal quotation marks omitted)). The deference given to EPA to make scientific judgments . about climate change is consistent with the Supreme Court's holding in American Elec. Power Co., Inc. v. Connecticut, 131 S. Ct. 2527, 2539-40 (2011); See Hari M. Osofsky, AEP V. Connecticut's Implications for the Future of Climate Change Litigation, 121 YALE L.J. ONLINE 101 (2011), available at http://yalelawjournal.org/2011/09/13/osofsky.html.

66 Coalition, 684 F.3d at 119-22.

67 Id. at 126. In other words, the argument goes, because adoption of the Tailpipe Rule triggered GHG permitting under Prevention of Significant Deterioration, EPA should have considered the cost, not only of the Tailpipe Rule in isolation, but also the cost to industry to permit major sources of GHGs.

68 Id. 
automatic nature of Prevention of Significant Deterioration regulation after the finding in Massachusetts that GHG is an air pollutant. ${ }^{69}$

The petitioners next challenged the assumption by EPA that the term "any air pollutant" has the same meaning under the Prevention of Significant Deterioration program as the term was expansively applied to vehicle emissions in Massachusetts. ${ }^{70}$ In response, the court rejected each of the petitioners' arguments as to why "any air pollutant" has a more narrow meaning for Prevention of Significant Deterioration purposes than under section 202(a)(1) for purposes of vehicle emissions, ${ }^{71}$ including the petitioners' argument that the program only should apply to air pollutants that are NAAQS criteria pollutants. ${ }^{72}$

As to the term "major emitting facility," the court applied the requirement that courts should give effect to the express intent of Congress when interpreting agency regulations. ${ }^{73}$ The court thus held that, because the term "major emitting facility" is defined in CAA section 169 as a source that emits or has the potential to emit above the statutory threshold of "any air pollutant" (and GHGs are now indisputably "air pollutants"), then the Prevention of Significant Deterioration program automatically applied to major sources of GHG emissions when the Tailpipe Rule took effect. ${ }^{74}$

As anticipated, the petitioners finally argued that the administrative law doctrines of "absurd results," "administrative necessity," and "one-step-at-atime" advanced by EPA to support the Tailoring Rule did not allow EPA to rewrite the permitting thresholds of $100 / 250$ tons per year expressly set forth in the $\mathrm{CAA}^{75}$ Rather than proceeding to apply the Chevron standards to the

69 First, the court notes that the word "shall" in section 202(a)(1) effectively requires the Administrator to adopt regulations to control emissions from motor vehicles after a finding of endangerment to public health or welfare. Id. at 126-27. Second, the court holds the reference in section 202(a)(2) to compliance costs that must be considered by EPA only encompasses the cost to the auto industry, not the cost to major stationary sources of GHGs of the automatic regulation. Id. at 128 . The petitioners referred to this automatic system of GHG regulation under the Prevention of Significant Deterioration program as a "shell game" to avoid consideration of the cost of GHG regulation to stationary sources. Id. The court, in response, holds that the petitioners' argument is just an attempt to avoid the plain text of section 202(a). Id. at 129.

70 Id at $133-34$.

71 Id.

72 See id. at 135-44. More specifically, the court rejected the petitioners' arguments that 1) Prevention of Significant Deterioration only applies to air pollutants that pollute locally; 2) if Prevention of Significant Deterioration does apply to GHGs, it should only apply to sources that emit over the threshold of an NAAQS criteria pollutant in an area designated as in attainment or unclassifiable for that pollutant (citing CAA $\S 163(\mathrm{~b})(4), 42$ U.S.C.S. $₹ 7473(\mathrm{~b})(4)$ ), where the term "any air pollutant" is used in conjunction with "any area to which this part applies"); and 3) that EPA failed to follow the steps required to designate new NAAQS pollutants, including a one year delay for the effective date, basically reiterating that "any air pollutant" means "any air pollutant." Id. at 138-40.

73 Id. at $133-34$.

74 Id.

75 Id. at 145 ("Petitioners-particularly State Petitioners-argue that none of these doctrines permit EPA to 'depart unilaterally from the [CAA's] permitting thresholds and replace them with numbers of its own choosing.') (citing State Pet'rs' Timing \& Tailoring Br. 29). 
express thresholds in the statute (as the court did with the term "major emitting facility"), the court instead denied the petitioners' challenges of the Timing and Tailoring Rules based on a lack of standing. ${ }^{76}$

Although the court recognized based on Massachusetts that the state petitioners were entitled to a "special solicitude" in any standing analysis, the court nevertheless held that the petitioners still were required to establish a concrete and particularized injury in fact and failed to do so. ${ }^{77}$ First, the court held that because the CAA mandated the regulation of GHGs, the Timing and Tailoring Rules helped, not harmed, the regulated industry and the states that must permit and monitor compliance. ${ }^{78}$ Without the Tailoring Rule, the court reasoned, "an even greater number of industry and state-owned sources would be subject to Prevention of Significant Deterioration and Title V, and state authorities would be overwhelmed with millions of additional permit applications.." ${ }^{78}$

Second, the court addressed the state petitioners' argument as to the ability of the court to provide a remedy-namely, that if the Tailoring Rule is struck down, Congress would be forced to enact legislation to correct the administrative train wreck. ${ }^{80}$ Citing "Schoolhouse Rock" for the proposition that a generation of schoolchildren know that "it's very unlikely that [a bill will] become a law," the court held there was no guarantee that Congress would act or what action Congress might take; thus, the standing requirement was not satisfied that a favorable decision would likely-rather than speculatively-redress any injury caused by the new Prevention of Significant Deterioration regulations. ${ }^{81}$

Finally, the court rebuked the state petitioners' alternative argument that the Tailoring Rule results in environmental harm to the states because it fails to regulate GHGs at the levels actually set forth in the statute, subjecting the states to additional injury from climate change. ${ }^{82}$ As to this argument, the court found that state petitioners were not permitted to raise

76 Id. at 146. Although commentators agree that Congress did not intend the Prevention of Significant Deterioration provisions to apply to small entities, they disagree as to whether that fact supports the arguments of EPA or the petitioners. See, e.g., Nathan D. Riccardi, Note, Necessarily Hypocritical: The Legal Viability of EPA's Regulation of Stationary Source Greenhouse Gas Emissions Under the Clean Air Act, 39 B.C. ENVTL. AFF. L. REv. 213, 240 (2012); cf. Allen \& Lewis, supra note 16, at 933.

77 Coalition, 684 F.3d at 148. Although the "special solicitude" of states was a significant basis used by the Court to find standing in Massachusetts, a lead EPA counsel in the case has acknowledged that EPA never mentioned the concept in its brief because counsel itself believed, based on Alfred L. Snapp \& Son, Inc. v. Puerto Rico ex rel. Barez, 458 U.S. 592 (1982), that special solicitude standing does not apply when states sue the federal government. Lisa Heinzerling, Climate Change in the Supreme Court, 38 EnvTL. L. 1, 16 (2008).

78 Coalition, 684 F.3d at 146.

79 Id. In other words, because the Tailoring Rule resulted in less, not more, regulation, the petitioners suffered no harm.

80 Id. at $146-47$.

81 Id. at 147 (citing Schoolhouse Rock, I'm Just a Bill at 2:41, available at http://www.you tube.com/watch?v=tyeJ55o3El0 (last visited July 21, 2013)).

82 Id. at 147. 
climate change injury as a basis for standing because the argument was not raised until state petitioners' reply brief, holding that "where standing is not self-evident, 'in its opening brief, the petitioner should ... include... a concise recitation of the basis upon which it claims standing". 83

Consider the dilemma faced by the petitioners in framing their arguments. The petitioners could not have framed their standing argument in their opening brief to the satisfaction of the court by alleging injury from climate change without also compromising their arguments as to the Endangerment Finding. The petitioners sought for the court to strike down the entire complex legal structure leading to the regulation of GHGs under the Prevention of Significant Deterioration program, including not only the Tailoring Rule, but also the Endangerment Finding. ${ }^{84}$ It seems rather inconceivable that the petitioners could argue that they were injured by the over-regulation of GHGs under Prevention of Significant Deterioration while at the same time making the argument that they were injured by the underregulation of GHGs.

Industry was not and is not done fighting over the regulation of GHG emissions under the Prevention of Significant Deterioration program. On August 10, 2012, industry groups requested an en banc rehearing of the D.C. Circuit's decisions in Coalition, ${ }^{85}$ and on October 12, 2012, EPA filed its response in opposition. ${ }^{86}$ Then on December 20, 2012, voting 6-2, the D.C. Circuit denied the request for an en banc rehearing. ${ }^{87}$ Judge David $B$. Sentelle, writing for the majority, stated that "[t]he legal issues presented ... are straightforward, requiring no more than the application of clear statutes and binding Supreme Court precedent." ${ }^{88}$ Circuit Judge Janice R. Brown, writing in dissent, acknowledged that while in an ordinary case the possibility of corrective legislation is insufficient to establish standing, the choice between non-action or an "absurd" regulation is not an ordinary

83 Id. at 147-48 (quoting Sierra Club v. EPA, 292 F.3d 895, 901 (D.C. Cir. 2002). The court also charged the state petitioners with "fail[ure] to cite any record evidence to suggest that they are adversely affected by global climate change." Id. at 148. So after finding that Massachusetts affirmatively held that GHG is an air pollutant, that EPA had no choice but to regulate GHG, and that EPA relied on sound science to establish that GHG causes harm to health and welfare, for the opposite purpose of challenging EPA's regulation of GHG in direct contravention of the express provisions of the Clean Air Act, the harm to the health and welfare of the citizens of the state petitioners is not "self-evident." Id. at 147-48. Query whether the court would require the state petitioners to submit the exact same reports that EPA relied on to support the Endangerment Finding.

84 Coalition, 684 F.3d at 149 ; id.

85 Chamber of Commerce of the United States of America's Combined Petition for Panel Rehearing or for Rehearing En Banc, Coalition, 684 F.3d 102 (No. 10-1073); Petition for Rehearing En Banc, submitted by the National Association of Manufacturers and other nongovernmental petitioners Coalition, 684 F.3d 102 (No. 10-1073).

86 EPA's Response to Petitions for Rehearing En Banc, 684 F.3d 102 (No: 10-1073).

87 Order Denying Petition, 684 F.3d 102 (No. 09-1322).

88 Coalition for Responsible Regulation, Inc. v. U.S. Envtl. Prot. Agency, 2011 WL 6621285, at *3, 4 (No.10-1073)(D.C. Cir. 2012). 
case. ${ }^{80}$ Circuit Judge Brett M. Kavanaugh in a separate dissent, attacked the court's deference to EPA's definition of "any air pollutant," writing that while GHGs may be an air pollutant under CAÁ section 202(a)(1) for purposes of tailpipe emissions, GHGs should not be considered an air pollutant under the Prevention of Significant Deterioration program, which he believes is limited to NAAQS criteria pollutants. ${ }^{90}$ Nine separate petitions for writ of certiorari subsequently were filed with the Supreme Court for review of the Coalition decision, including separate petitions from Texas and eleven other states, Virginia, and a coalition of industry and utility groups. ${ }^{91}$ Although the Supreme Court may decide not to wade into the messy arguments in light of Massachusetts, ${ }^{92}$ the persuasive dissent of Judge Kavanaugh provides the petitioners at least some chance of Supreme Court review.

\section{B. Implications of PSD GHG Regulation for the Oil and Gas Industry}

Commentators on both sides of the aisle appear to agree that after the decision in Coalition, the Tailpipe Rule and the regulation of GHG major sources under the Prevention of Significant Deterioration program are the alpha, not the omega, of GHG regulation by EPA ${ }^{93}$ Absent Supreme Court intervention, Coalition represents a new era, seemingly authorizing unbridled regulation by EPA of GHGs under a statute that was never written in contemplation of climate change. This Part explains some of the burdens and impacts on the oil and gas industry of the Prevention of Significant Deterioration program, as well as some potential streamlining approaches that have been considered but not adopted.

\section{Source Categories Brought Into PSD Review Because of GHG Emissions}

The permitting effect on the oil and gas industry of GHG regulation under Prevention of Significant Deterioration will be substantial as new stationary sources are constructed and modifications are made to existing sources. For example, the American Petroleum Institute (API) has identified

89 Id. at 22 (Brown, J., dissenting).

90 See id. at 3-17 (Kavanaugh, J., dissenting).

91 See, e.g., Petition for Writ of Certiorari, Coalition, 684 F.3d 102 (No. 09-1322); see, e.g., Petition for Writ of Certiorari, American Chemistry Counsel v. EPA (No. 10-1167); see, e.g., Petition for Writ of Certioriari, Virginia v. EPA (No. 09-1322).

92 See Megan Herzog, Industry Coalition Petitions for Supreme Court Review of D.C. Circuit Decision on Greenhouse Gas Rules, LEGAL PLANET, Apr. 19, 2013, http://legal planet.wordpress.com/2013/04/19/industry-coalition-petitions-for-supreme-court-review-of-d-ccircuit-decision-on-greenhouse-gas-rules/ (last visited July 21, 2013).

93 .These rulings clear the way for EPA to keep moving forward under the Clean Air Act to limit carbon pollution form motor vehicles, new power plants and other big industrial sources." U.S. Court Upholds EPA's Greenhouse Gas Rules, Coalition for Responsible Regulation v. EPA, 32 No. 25 Westlaw ENVTL.. 1, (July 3, 2012) (quoting David Doniger, senior attorney at the Natural Resources Defense Council). 
the following source categories brought into major source review under existing thresholds solely because of GHG emissions in each of 1) the upstream (exploration and production activities), 2) mid-stream (natural gas gathering, processing, and transmission activities), and 3) downstream (pipeline transportation, refining, and marketing activities) industry segments: ${ }^{94}$

- Upstream activities potentially subject to GHG permitting include flaring of associated gas from the production of oil and steamintensive production activities.

- Midstream operations potentially subject to GHG permitting include either new facilities or modifications to compressor stations, processing plants, and $\mathrm{CO}_{2}$ removal operations (acid gas treatment).

- Downstream operations potentially subject to GHG permitting include refining operations, modifications to cogeneration projects, the addition of boilers or combustion turbines, and hydrogen production/adding hydrogen production capacity. Specifically, API stated that the GHG permitting threshold applies to boilers, heaters, turbines, and reciprocating engines with fuel usage of natural gas of $196 \mathrm{MMBt} / \mathrm{hour}$ or distillate of $140 \mathrm{MMBtu} /$ hour. $^{95}$

For the upstream industry segment, additional emissions sources could also be swept into the GHG Prevention of Significant Deterioration permitting analysis in any EPA Region that continues to attempt to aggregate upstream oil and gas production operations, despite a recent Sixth Circuit holding striking down the aggregation of multiple wells and a gas processing plant as a single source. ${ }^{98}$

\section{Lowering of GHG Emissions Thresholds - Adding Sources}

As discussed above, under EPA's "one-step-at-a-time" approach, EPA intends to revisit the GHG permitting thresholds under the Prevention of Significant Deterioration program by April 16, 2016, and as often thereafter

94 The term downstream "is often used to describe post-production processes which are deemed downstream operations." PaTriCK H. MarTin \& BRUCE M. KRAMER, WILLIAMS \& MEYERS, MANUAL OF OLL \& GAS TERMS 280 (13th ed. 2006). "Production is an upstream operation and marketing is a downstream operation when the refinery is used as a point of reference." Id. at 1115.

95 Am. Petroleum Inst, API Responses to CAAAC GHG Streamlining Workgroup QUESTIONS 93-94 (June 18, 2012) [hereinafter API STREAMLINING RESPONSE], attached to CLEAN Air Act AdVISORY Comm. GHG Permit Streamlining WorkgrouP, Air Permitting Streamlining TECHNIQUES AND APPROACHES FOR GREENHOUSE GASES: A REPORT TO THE U.S. ENVIRONMENTAL PROTECTION AGENCY (FINAL REPORT) (Sept. 14, 2012), available at http://www.epa.gov/nsr/ghg docs/20120914CAAACPermitStreamlining.pdf [hereinafter STREAMLINING REPORT].

96 See Summit Petroleum Corp. v. EPA, 690 F.3d 733 (6th Cir. 2012) (vacating EPA's determination that a natural gas processing plant and approximately 100 wells conștitute a single stationary source for Title V purposes as they are not "adjacent" or "contiguous"). 
as it considers appropriate. ${ }^{97}$ Lower thresholds have the potential to add significantly more oil and gas industry sources whether or not aggregation is considered for major source determination. ${ }^{98}$

\section{Administration Burdens}

\section{a. Permitting and Review}

The Prevention of Significant Deterioration program requires an extensive review process in connection with the application for a construction permit for new construction or a major modification that includes a detailed analysis prepared by the source of the best available control technology (BACT) to control emissions of the applicable pollutant. ${ }^{9 \theta}$ After the control technology is determined, an enforceable emissions limit is then determined for each pollutant subject to the program on a case-by-case basis based on the selected control technology. ${ }^{100}$ The control technology, emissions limits, monitoring, recordkeeping, and reporting requirements are then incorporated into a draft air construction permit that only becomes final after an extensive review process that includes reviews by state and federal agencies, a public comment period, response to public comments, and potential administrative or judicial appeals. ${ }^{101}$ Sources with construction permits under Prevention of Significant Deterioration are then required to roll over the construction permit requirements into a Title $\mathrm{V}$ operating permit. $^{102}$

Other analyses and related reviews in connection with a Prevention of Significant Deterioration permit application include an ambient air quality analysis; a soils, vegetation, and visibility analysis related to "associated growth"; and a Class I area (e.g., some national parks and wilderness areas) impact analysis to address the impact of emissions on the attainment of

97 See discussion supra at Part II.A.3.

98 See supra note 96 and accompanying text.

9940 C.F.R. $\$ 52.21(\mathrm{j})(2)-(3)(2012)$. BACT is defined as "an emissions limitation (including a visible emission standard) based on the maximum degree of reduction for each pollutant subject to regulation under [the] Act which would be emitted from any proposed major stationary source or major modification which the Administrator, on a case-by-case basis, taking into account energy, environmental, and economic impacts and other costs, determines is achievable for such source or modification through application of production processes or available methods, systems, and techniques, including fuel cleaning or treatment or innovative fuel combustion techniques for control of such pollutant... If the Administrator determines that technological or economic limitations on the application of measurement methodology to a particular emissions unit would make the imposition of an emissions standard infeasible, a design, equipment, work practice, operational standard, or combination thereof, may be prescribed instead to satisfy the requirement for the application of best available control technology ..." Id. § 52.21(b)(12).

100 See Prevention of Significant Deterioration (PSD) and Nonattainment New Source Review (NSR), 61 Fed. Reg. 38,271-72 (July 23, 1996).

101 See generally CLEAN AIR ACT HANDBOOK, supra note 47, at 140-80.

102 See 40 C.F.R. § 70.1(a)-(b) (2012). 
national ambient air quality standards. ${ }^{109}$ The American Petroleum Institute argues that while considerations of GHGs do not generally impact those analyses, the requirement that all regulated NSR pollutants, such as nitrogen dioxide and sulfur dioxide be analyzed for emissions and the potential to emit above significance levels (but below the 100/250 tons per year threshold levels) have required dubious capital expenditures that would not have been required before GHG regulation under Prevention of Significant Deterioration. $^{104}$

Finally, additional steps are currently required for sources in Texas. EPA has been the permitting authority for GHGs in Texas under a Federal Implementation Plan (FIP) while the state battles with EPA in court over the state's GHG air permitting program. ${ }^{105}$ Despite the ongoing litigation, Texas Governor Rick Perry signed legislation that requires the Texas Commission on Environmental Quality (TCEQ) to develop a state GHG permitting

103 See Clean Air Act, 42 U.S.C $\$ 7471$ (2006) (ambient air quality analysis); id. § 7472(a) (protection of Class I areas); id. $\S \S 7475(\mathrm{a})(6),(\mathrm{e})(3)(\mathrm{B})$ (associated growth); see also 40 C.F.R. $\S 52.21(\mathrm{o})(2012)$.

104 API STREAMLINING RESPONSE, supra note 95, at 89.

105 On December 13, 2010, EPA issued a finding that thirteen states had SIPs that were "substantially inadequate" to implement Prevention of Significant Deterioration permitting consistent with the Tailoring Rule. Action to Ensure Authority to Issue Permits Under the Prevention of Significant Deterioration Program to Sources of Greenhouse Gas Emissions: Finding of Substantial Inadequacy and SIP Call, 75 Fed. Reg. 77,698 (Dec. 13, 2010). Of the thirteen states, twelve accepted deadlines to implement SIPs, seven of which accepted deadlines before January 2, 2011. See Action to Ensure Authority to Issue Permits Under the Prevention of Significant Deterioration Program to Sources of Greenhouse Gas Emissions: Finding of Failure To Submit State Implementation Plan Revisions Required for Greenhouse Gases, 75 Fed. Reg. 81,874 (Dec. 29, 2010). The State of Texas, however, refused to accept a deadline to revise its state implementation plan. See Letter from Bryan W. Shaw, Ph.d., Chairman, Tex. Comm'n on Envtl. Quality and Greg Abbott, Att'y Gen. of Tex., to Lisa Jackson, Adm'r, EPA, and Dr. Alfredo “Al” Armendariz, Reg'l Adm'r, EPA, Region 6 (Aug. 2, 2010) available at http://www.tceq.texas.gov/assets/public/comm_exec/epa.pdf ("In order to deter challenges to your plan for centralized control of industrial development through the issuance of permits for greenhouse gases, you have called upon each state to declare its allegiance to the Environmental Protection Agency's recently enacted greenhouse gas regulations-regulations that are plainly contrary to United States law"). EPA issued an interim final rule and final rule on December 30,2010, and May 3, 2011, respectively, which retroactively (back to 1992 when EPA approved the Texas PSD SIP) partially disapproved the Texas Prevention of Significant Deterioration State Implementation Plan and imposed a Federal Implementation Plan for regulation of greenhouse gas sources in Texas. See Determinations Concerning Need for Error Correction, Partial Approval and Partial Disapproval, and Federal Implementation Plan Regarding Texas Prevision of Significant Deterioration Program (Interim Final Rule), 75 Fed. Reg. 82,430 (Dec. 30, 2010); see also Determinations Concerning Need for Error Correction, Partial Approval and Partial Disapproval, and Federal Implementation Plan Regarding Texas's Prevention of Significant Deterioration Program (Final Rule), 76 Fed. Reg. 25,178 (May 3, 2011). Not to be outdone, Texas sued EPA. See Petition for Review, Texas v. U.S. Envtl. Prot. Agency, No. 10-1425 (D.C. Cir. Feb. 8, 2012) (decision pending). Oral arguments in this and a related case, Utility Air Regulatory Grp. v. EPA, No. 11-1037 (decision pending), were heard by the D.C. Circuit on May 7, 2013. See D.C. Circuit Oral Argument Calendar (Sept. 10, 2012 - May 16, 2013), available at http://www.cadc.uscourts.gov/internet/home.nsf/Content/Oral+Arguments (last visited July 21, 2013). 
program, ${ }^{106}$ with broad support from industry interests concerned with the additional requirements and permitting delays associated with the federal program. ${ }^{107}$ Although EPA recently relaxed requirements to obtain dual permits from both Texas and EPA for non-GHG pollutants when a source is required to seek a permit for $\mathrm{GHG},{ }^{108}$ until the Texas Administrative Code is amended and a permitting program approved by EPA is in place, a major source of GHGs must continue to coordinate with both TCEQ and EPA to meet state and federal requirements. ${ }^{109}$ The federal requirements include the preparation and review of a biological assessment and cultural resources report that is subject to review and approval under the Endangered Species $\mathrm{Act}^{110}$ and the National Historical Preservation Act. ${ }^{111}$

\section{b. Permit Avoidance}

Under the EPA's "major for one, major for all policy,"112 a new source with at least 100,000 tons per year of $\mathrm{CO}_{2}$ e emissions or an existing source proposing a 75,000 tons per year emissions increase is subject to Prevention of Significant Deterioration for any non-GHG pollutant with an emissions increase of GHG greater than the applicable "significance" level ${ }^{13}$ for the

106 H.B. 788, 83rd Leg., Reg. Sess. (Tex. 2013).

107 Daniel P. Berner et al., 2013 Texas Environmental Legislation Summary, NAT'L L. REv., June 29, 2013, http://www.natlawreview.com/article/2013-texas-environmental-legislationsummary (last visited July 21, 2013).

108 See Letter from Samuel Coleman, Deputy Reg'l Adm'r, EPA, to Zak Cover, Exec. Dir., Texas Comm'n on Envtl. Quality (Apr. 4, 2013), available at http://www.tceq.texas. gov/assets/public/ permitting/air/Announcements/from-epa-4-13.pdf; cf. EPA, Q \& A: ISSUING PERMTTS FOR SOURCES WITH DUAL PSD PERMITTING AUTHORITIES 1 (2011), available at http://www.tceq.texas.gov/assets/public/permitting/air/Announcements/from-epa-4-13.pdf.

109 See Letter from Samuel Coleman to Zak Covar, supra note 108.

110 Endangered Species Act of 1973,16 U.S.C. $\$ 1536(a)(2)$ (2006) (requiring that each federal agency ensure that any agency action is not likely to jeopardize the continued existence of any endangered species or threatened species).

111 National Historic Preservation Act, 16 U.S.C. $\S 470 f$ (2006) (requiring that each federal agency take into account the effect of the license of any district, site, building, structure, or object that is included in or eligible for inclusion in the National Register); Determinations Concerning Need for Error Correction, Partial Approval and Partial Disapproval, 75 Fed. Reg. at 82,430 .

112 See EPA, Q \& A: TRIGgering PSD at Non-ANyway SOURCES AND MOdifications 1, available at http://www.epa.gov/nsr/ghgdocs/TriggeringPSDatnonAnywaySourcesandMods. pdf ("The non-GHG pollutant(s) at the source will also become subject to PSD if the modification results in an emissions increase at or above the significance level for that nonGHG pollutant. Thus, EPA's longstanding 'major for one, major for all' PSD policy also applies to GHG-only major sources, but only after GHGs are determined to be subject to regulation for the modification.").

113 Significance levels vary for different pollutants. For example, while the significance level for carbon monoxide is 100 tons per year, the significance level for sulfur dioxide is 40 tons per year and the significance level for hydrogen sulfide is 10 tons per year. Significance may also mean any emissions for regulated NSR pollutants that are not listed or that are associated with a major stationary source or major modification within a certain distance of a Class I area for NAAQS purposes and that have a certain impact on that area. See 40 C.F.R. $\S 52.21$ (b)(23)(i)(ii) (2012); see also CleAN AIR ACT HANDBOOK, supra note 47, at 149. 
pollutant even if none of its non-GHG pollutant emissions are at major levels (i.e., above 100 tons per year or 250 tons per year, as applicable). ${ }^{114}$ This policy has caused a number of sources to seek federally-enforceable synthetic minor permits to attempt to stay out of Prevention of Significant Deterioration for non-GHG pollutants. ${ }^{116}$ Under such a "PSD avoidance permit," the source must limit emissions below the Prevention of Significant Deterioration GHG thresholds, which avoids lengthy and detailed BACT determinations, but also limits the ability of the source to increase production capacity. ${ }^{116} \mathrm{EPA}$ has not granted itself the regulatory authority to issue synthetic minor permits in states that are subject to a GHG Prevention of Significant Deterioration Federal Implementation Plan (e.g., Texas), although it considered granting itself such authority and declined to do so in its Step 3 rulemaking. ${ }^{17}$

EPA has highlighted that the number of GHG permit applications actually submitted has been smaller than anticipated. ${ }^{118}$ This trend likely has occurred in part because sources expedited projects before the Tailoring Rule effective date and in part because Prevention of Significant Deterioration permitting is so burdensome and difficult that companies have elected not to pursue projects that would have been otherwise economically beneficial. ${ }^{110}$ On the other hand, the availability of synthetic minor GHG permits may also contribute to the lower than expected number of applications. ${ }^{120}$

\section{c. Best Available Control Technology}

BACT is the maximum emissions reduction that the Administrator determines on a case-by-case basis is achievable by applying systems, methods, and techniques to control the pollutant, and may include new equipment, designs, work practices, operational standards, or a combination thereof. ${ }^{121}$ The determination of what constitutes BACT generally is a topdown approach that considers five steps: 1) identification of all available control technologies; 2) elimination of technically infeasible options; 3) ranking remaining control technologies; 4) evaluation of the most effective

\footnotetext{
11440 C.F.R. \& $51.166(b)(1)(i)(1987)$.

115 See STREAMLINING REPORT, supra note 95, at 15.

116 See Peter Glaser, First Year of GHG Permitting Under Prevention of Significant Deterioration Program, ElectRIC Light \& POWER, May-June 2012, at 28. As an example, the author describes such a permit issued to The Northern Natural Gas Co. by the Minnesota Pollution Control Agency that, inter alia, includes a statement that "a limit on greenhouse gas emissions (as carbon dioxide equivalent, $\mathrm{CO}_{2} \mathrm{e}$ ) was added to the permit, because the permittee wishes to remain a non-major source under New Source Review." Id.

117 GHG PSD Step 3 Rulemaking, supra note 58, at 41,053.

118 Id. at 41,056-57 (noting that states have also seen budget cuts and decreases in staffing levels, and that the less than expected number of permits is likely partially attributable to the economy).

119 API STREAMLINING RESPONSE, supra note 95, at 91-92.

120 GHG PSD Step 3 Rulemaking, supra note 58 , at 41,055 .

12140 C.F.R. § 52.21(b)(12) (2012).
} 
controls and documentation of results; and 5) selection of the technology. ${ }^{122}$ EPA has issued a general guidance document relating to GHG that includes a discussion of BACT, ${ }^{123}$ as well as a series of technical white papers relating to certain industrial sectors that are discussed in more detail below.

\section{i. General Guidance}

The general guidance document issued by EPA includes a number of points that are particularly important for the oil and gas industry. For example, EPA notes that a Step 1 list of options need not include inherently lower polluting processes that would fundamentally "redefine the nature of the source proposed by the permit application" and that BACT should not be applied to "regulate the applicant's purpose or objective for the proposed facility." ${ }^{124}$ Accordingly, any GHG Prevention of Significant Deterioration permit application should necessarily begin with a detailed discussion of the nature of the oil and gas operations applicable to the source and its goals, objectives, purpose and basic design. Further, "[i]n circumstances where there are varying configurations for a particular type of source, the applicant should include in the application a discussion of the reasons why that particular configuration is necessary to achieve the fundamental business objective for the proposed construction project."125

EPA emphasized energy efficiency for GHGs because add-on controls to reduce GHG emissions are not as advanced as those already developed for other combustion-derived pollutants. ${ }^{126}$ In addition to unit specific efficiency measures, sources have the flexibility to consider facility-wide energy efficiency strategies rather than limiting controls to the particular emissions units that are modified or constructed, with EPA specifically

122 See EPA, New SOURCe Review Workshop MANUAL, B.6-B.7 (Oct. 1990), available at http://www.epa.gov/ttn/nsr/gen/wkshpman.pdf; see also Memorandum from Craig Potter, Assistant Adm'r for Air and Radiation, EPA, to Regional Adm'rs, (Dec. 1, 1987), available at http://www.epa.gov/region07/air/nsr/nsrmemos/establsh.pdf. EPA has not established the topdown approach as a binding requirement through rule, see Alaska Dept. of Envtl. Conservation v. U.S. Envtl. Prot. Agency, 540 U.S. 461, 476 n.7 (2004), although given EPA's strong preference for the top-down approach in its guidance, see U.S. ENVTL. PROT. AGENCY, PSD AND TTTLE V PERMITTING GUIDANCE FOR GREenHOUSE GASES, 17-19 (2011) , available at http://www.epa.gov /nsr/ghgdocs/ghgpermittingguidance.pdf [hereinafter GENERAL PERMTTING GUIDANCE], a source would be wise to follow that approach.

123 See generally GENERAL PERMITTING GUIDANCE, supra note 122.

124 Id. at 26. For example, EPA states that "permitting authorities can show in most cases that the option of using natural gas as a primary fuel would fundamentally redefine a coal-fired electric generating unit." Id. at 27.

125 Id. at 27.

126 Id at 29. Energy efficiency improvement measures are discussed in two categories: 1) technologies or processes that maximize energy efficiency of individual units, such as the use of combined cycle combustion turbines rather than simple cycle turbines, with respect to a natural gas facility, and 2) technologies and process at new facilities that reduce the facility's overall energy utilization (assuming reductions in on-site emissions) such as designing a boiler system for heat exchangers to use the steam generated from the boiler. Id. at 29-31. 
recommending industrial sector performance benchmarking. ${ }^{127}$ That said, energy efficiency options may not include reductions in demand for energy from the electric grid (i.e., offsite energy efficiency) that cannot be demonstrated to achieve emissions reductions within the property boundary. ${ }^{128}$

EPA insists that carbon capture and sequestration (CCS) be considered in every BACT review by treating CCS as an "available control technology" that must either be eliminated or ranked under the top-down approach with detailed site-specific facility data. ${ }^{129}$ The American Petroleum Institute argues in response that CCS is not "available," and therefore, that consideration of CCS provides no environmental benefit but can add threeto-six months to the permit preparation and review time. ${ }^{130}$

In performing the evaluation of the most effective controls and documentation of results, permitting authorities must consider economic, energy, and environmental impacts relating to remaining technology options, which EPA states should include increased heat waves, increased intensity of hurricanes and floods, and increased severity of coastal storms as relates to GHG emissions. ${ }^{131}$ After annunciating this irrational requirement, given the negligible and incalculable contribution of any particular source to natural disasters, EPA basically stated that it is just kidding. Permitting authorities need not focus on those environmental impacts, but instead should focus on a comparison of GHG emissions to impacts resulting from collateral emissions increases of other regulated NSR pollutants. ${ }^{132}$

Finally, to the extent EPA completes New Source Performance Standards for a relevant source category, BACT determinations must consider the levels of the GHG standards and supporting rationale for the New Source Performance Standards. ${ }^{133}$ As discussed below, proposed GHG

127 Id. at 21-22 (recommending performance benchmarking against ENERGY STAR sectorspecific benchmarking tools called plant Energy Performance Indicators (EPIs), which can be found for industrial sectors at http://www.energystar.gov/EPIS).

128 Id. at 24.

129 U.S. ENVTL. PRot. AgENCY, RePort of the INTERAGENCY TASK ForCE ON CARBon CAPTURE AND STORAGE 50 (2012), available at $\mathrm{http} / / \mathrm{www}$.epa.gov/climatechange/Downloads/ccs/CCSTask-Force-Report-2010.pdf. In one particular determination of permit completeness, EPA states: "Please provide site-specific facility data to evaluate and eliminate CCS from consideration. This material should contain detailed information on the quantity and concentration of $\mathrm{CO}_{2}$ that is in the waste stream and the equipment for capture, storage and transportation. Please include cost of construction, operation and maintenance, cost per pound of $\mathrm{CO}_{2}$ removed by the technologies evaluated and include the feasibility and cost analysis for storage or transportation for these options." Letter from Envtl. Prot. Agency, Region 6, to Greg Corcoran, Vice President \& Gen. Manager, Diamond Shamrock Ref. Co., L.P. (June 5, 2012), available at http:/www.epa.gov/region6/6pd/air/pd-r/ghg/diamond-shamrock-comp-deter060512. pdf.

130 API STREAMLINING RESPONSE, supra note 95, at 88. As API notes, EPA's own GHG permitting guidance provides that BACT "generally should not be applied to regulate an applicant's purpose or objective for the proposed facility." Id.

131 GenERAL PERMTTTING GUIDANCE, supra note 122, at 40-41.

132 Id.

133 Id. at $20-21$. 
New Source Performance Standards may be on the horizon for refineries and for the midstream and upstream oil and gas industry segments that could also become important standards for GHG Prevention of Significant Deterioration permitting actions. ${ }^{134}$

\section{ii. Specific Guidance}

EPA has issued a number of industry white papers that describe available and emerging technologies to be considered in the first step of the top-down BACT analysis, including one specific to refineries. ${ }^{135}$ Although EPA has not issued guidance for the upstream or midstream oil and gas industry segments, portions of the refinery guidance likely will be applicable to those segments. The following is a summary of certain recommendations in the guidance issued for refineries: .

- Energy Efficiency Initiatives and Improvements - Improve process monitoring and control systems; use high efficiency motors; use variable speed drives; optimize compressed air systems; implement lighting system efficiency improvements.

- Steam Generating Boilers - Minimize steam generation at excess pressure or volume; use turbo or steam expanders when excesses are unavoidable; schedule boilers based on efficiency; use oxygen monitors and intake air flow monitors; improve insulation; improve maintenance; recover heat from process fuel gas; recover steam from blowdown; install steam condensate return lines.

- Process Heaters - Use oxygen monitors and intake air flow monitors; use air preheater package for heat recovery.

- Combined Heat and Power - Use internally generated fuels or natural gas for power production.

- Fuel Gas System - Use dry seal rather than wet seal compressors; use rod packing for reciprocating compressors; use organic vapor analyzer or optical sensing technologies for leak detection and repair; evaluate sulfur scrubbing technologies.

- Flares - Install flare gas recovery compressor systems; maintain flare combustion efficiency; use refrigerated condensers.

- Sulfur Recovery Systems - Evaluate energy and $\mathrm{CO}_{2}$ intensity in selection of sulfur recovery unit and tail gas treatment systems.

134 See discussion infra Part III.B.

135 U.S. Envtl. Prot. Agency, Avallable and Emerging Technologies for Reducing Greenhouse Gas Emissions From the PEtroleum Refining Industry (2010), available at http://www.epa.gov/nsr/ghgdocs/refineries.pdf [hereinafter REFINERY GUIDANCE]. 
- Hydrogen Production Units - Consider using additional catalytic reforming units to produce $\mathrm{H} 2$; use heat recovery systems; use cogeneration of hydrogen and electricity.

- Storage Tanks - Consider use of a vapor recovery or control systems; insulate heated storage tanks.

- Carbon Capture - Oxy-combustion (the process of burning a fuel in the presence of pure or nearly pure oxygen instead of air); postcombustion solvent capture and stripping; post-combustion membranes. ${ }^{136}$

Major sources of GHGs in the oil and gas industry may also find helpful white papers issued for other industries, such as the iron and steel industry, electric generating units, and large industrial/commercial/institutional boilers, ${ }^{137}$ although such papers should be updated by EPA and EPA should consider providing additional white papers specific to the mid-stream oil and gas industry. Sources should also review information about pollution control measures required for other sources available at the RACT/BACT/LAER Clearinghouse. ${ }^{138}$

\section{d. Potential Streamlining Approaches}

If they would ever be endorsed by EPA, streamlining approaches could decrease compliance costs by the use of standardized technologies, systems, permits, and approvals, which could benefit oil and gas industry operators struggling to comply with a myriad of new requirements. ${ }^{130}$ In the Tailoring Rule, EPA committed to the development of permit streamlining approaches, specifically to the exploration of a "wide range of possible approaches before the Step 3 rulemaking. ${ }^{110}$ However, the only streamlining approach actually adopted by EPA in its Step 3 rulemaking was to revise the

136 See id. at 13.

137 See, e.g., U.S. Envtl. Prot. Agency, Office of Air and Radiation, Avallable and EMERGING TECHNOLOGIES FOR REDUCING GREENHOUSE GAS EMISSIONS FROM THE IRON AND STEEL INDUSTRY (2012), available at http://www.epa.gov/nsr/ghgdocs /ironsteel.pdf; U.S. ENVTL. PROT.

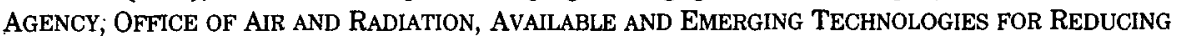
GREENHOUSE GAS EMISSIONS FROM COALFTRED ELECTRIC GENERATING UNITS (2010), available at http://www.epa.gov/nsr/ghgdocs/electricgeneration.pdf; U.S. ENVTL. PROT. AGENCY, OFFICE OF air and Radiation, Avallable and Emerging Technologies for Reducing Greenhouse Gas EMISSIONS FROM INDUSTRIAL, COMMERCIAL, AND INSTITUTIONAL BOILERS, (2010), available at http://www.epa.gov/nsr/ghgdocs/iciboilers.pdf.

138 See U.S. Envtl. Prot. Agency, RACT/BACT/LAER Clearinghouse, http://cfpub.epa.gov /RBLC/ (last visited July 21, 2013). In reviewing the Clearinghouse on December 3, 2012, the author found categories, but no entries, for "Oil and Gas and Field Services," and "Natural Gas/Gasoline Processing Plants," and only a single entry under "Other Petroleum/Natural Gas Production \& Refining Sources."

139 Seth Cox, A Regulatory Reinterpretation to Blow Away Dirty Energy?, 17 Mo. EnVTL. L. \& POL'Y REv. 258, 266-68 (2010).

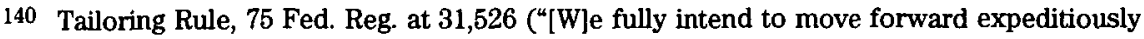
with developing streamlining approaches."). 
existing plant-wide applicability limitation (PAL) ${ }^{141}$ permitting program to allow permitting authorities to issue GHG plant-wide limits on either a mass basis or a $\mathrm{CO}_{2} \mathrm{e}$ basis. ${ }^{142}$ Environmental groups generally oppose streamlining approaches ${ }^{143}$ presumably because they tend to decrease compliance costs for sources.

The CAA Advisory Committee has submitted a report to EPA from its GHG Permit Streamlining Workgroup (the Workgroup) that contains a number of additional options and observations (i.e., other than PAL), but no actual opinions or recommendations that may be relied upon. ${ }^{144}$ The Workgroup specifically mentioned in the Streamlining Report that permit streamlining could help expedite permitting "if EPA proposes to expand the permitting programs to smaller sources and additional source categories of GHG emissions." 145

Streamlining options described by the Streamlining Report include: ${ }^{146}$

- Paring back or eliminating Prevention of Significant Deterioration review of other regulated pollutants for GHG-only major sources under the "major for one/major for all" policy. ${ }^{147}$ :

- Presumptive BACT. Under a "presumptive BACT" approach, a source need not identify, eliminate, rank, evaluate, and select best available control technology, but may use control technologies already approved by EPA for certain types of emissions units, thereby streamlining the process. ${ }^{148}$ Options such as presumptive BACT have been debated for years and would likely never receive consensus approval. $^{149}$

141 A PAL is an emissions limit for a single pollutant expressed in tons per year that is enforceable as a practical matter and is established source-wide in accordance with specific criteria. 40 C.F.R. $\S 52.21(\mathrm{aa})(2)(\mathrm{v})$ (2012). If a source can maintain its overall emissions of the PAL pollutant below the PAL level, the source can make a change without triggering Prevention of Significant Deterioration review. Id. $\$ 52.21$ (aa)(1)(ii).

142 See GHG PSD Step 3 Rulemaking, supra note 58 at 41,072 (July 12, 2012) (codified at 40 C.F.R. $\$$ 52.21(b)(49), (aa)(1)-(15)). The STREAMLINING REPORT, supra note 95, at 34-35, describes various problems with the use of PAL for GHG, including establishing the PAL baseline for GHGs, establishing the PAL baseline for landfill GHGs, monitoring provisions for a GHG PAL, resetting the PAL upon renewal, and establishing a GHG PAL for a greenfield (new) facility.

143 STREAMLINING REPORT, supra note 95 , at 15.

144 Id. at 2. The Streamlining Report contains a disclaimer that although the workgroup consisted of various "industrial, tribal, environmental and state/local” stakeholders, it does not reflect opinions or recommendations of EPA. Id.

145 Id. at 11.

146 Id. at $13-31$.

147 See supra note 113 and accompanying text.

148 STREAMLINING REPORT, supra note 95, at 18

149 API suggests that EPA develop presumptive BACT for natural gas combustion sources, such as package boilers, RICE engines, simple-cycle combustion turbines and combined-cycle combustion turbines. See API STREAMLINING RESPONSE, supra note 95, at 98. 
- Permits-by-Rule. A permit-by-rule establishes the requirements and limits in a rule as opposed to requiring a permit application and issuance of a permit.

- General Permits. A general permit is an expedited permit process with predetermined conditions that applies to an entire category of similar sources. Individual sources apply to be assigned to the general permit through a simple application process. ${ }^{150}$

- Minimizing or eliminating permitting for pollution control projects and energy efficiency projects that ironically discourage sources from undertaking such projects.

- Clarify that holding offsets and allocations under cap and trade programs should not be considered potential-to-emit GHG that factors into permitting thresholds.

- Eliminating or streamlining the analysis of carbon capture and sequestration in best available control technology reviews.

- Consideration of relevant New Source Performance Standards that concurrently control GHG emissions in the best available control technology analysis (such as the oil and gas production New Source Performance Standards that indirectly control methane emissions). ${ }^{151}$

- Consideration of state and local cap and trade programs in best available control technology analysis.

- Elimination of biogenic $\mathrm{CO}_{2}$ emissions from permitting considerations.

- Limiting application of Prevention of Significant Deterioration by "potential to emit" calculations through rules that provide that sources with actual emissions below a certain percent of the major source thresholds are minor sources and exempt.

- Handling GHG sources under minor source New Source Review only until there is a major modification for non-GHG emissions.

- Unit or source category specific exemptions by rule.

- Electronic permitting.

- Permits for equipment suppliers rather than for equipment owners/operators (certified equipment).

The Streamlining Report notes that although many state and local agencies already employ streamlining approaches for minor sources, any of

150 Specifically API notes that general permits issued under the Texas bifurcated permitting system (with four categories that cover oil and gas facilities in different groups of counties) have an average permitting time of twenty-seven to thirty-two days verses 364 days for a federal PSD permit. Id. at 96.

151 See infra Part III.B.3. 
the cited proposals would require formal agency rulemaking for major sources. ${ }^{152}$

\section{GHG as NAAQS Criteria Pollutant?}

Title I of the CAA distinguishes between so-called "criteria pollutants" that are listed by EPA under section 108 and "hazardous air pollutants" listed under section 112. ${ }^{153}$ To date EPA has chosen not to list GHG as a criteria pollutant. ${ }^{154}$ Such a listing, however, may be inevitable. GHG currently is in air pollutant no-man's land, categorized as neither a criteria pollutant nor a hazardous air pollutant.

If the Supreme Court grants a petition for certiorari and sides with Judge Kavanaugh's dissent that Prevention of Significant Deterioration only applies to criteria pollutants, then EPA could decide to go forward and list GHG as a criteria pollutant. Alternatively, a court could force EPA to list GHG under section 108 in response to a challenge by states and environmental groups, similar to the manner in which EPA was forced by the Supreme Court to make a GHG endangerment finding determination under section 202(a)(1) in Massachusetts. ${ }^{155}$ In fact, two environmental

152 STREAMLINING REPORT, supra note 95, at 16-17.

153 Clean Air Act, 42 U.S.C. $\S 7408$ (2006) (listing air quality criteria and control techniques). The CAA treats criteria pollutants that are "generally present in the ambient air in all areas of the nation" and "are generally detectable through monitoring devices and systems," S. REP. No. 91-1196, at 18 (1970), differently that "hazardous air pollutants" included in the list at section 112 (b)(1), 42 U.S.C. $\S 7412$ (b)(1) (2006), or added to that list under section 112(b)(2), 42 U.S.C. $\S 7412(\mathrm{~b})(2)$ (2006). The Administrator may designate "hazardous air pollutants" by rule which "present, or may present, through inhalation or other routes of exposure, a threat of adverse human health effects (including, but not limited to, substances which are known to be, or may reasonably be anticipated to be, carcinogenic, mutagenic, teratogenic, neurotoxic, which cause reproductive dysfunction, or which are acutely or chronically toxic). . ." 42 U.S.C. $\S 7412(b)(2)$ (2006). See also CLEAN AIR ACT HANDBOOK, supra note 47, at 14-15.

154 See ClEAN AIR ACT HANDBOOK, supra note 47, at 15.

155 CAA section 108(a)(1) states that the EPA Administrator shall from time to time revise a list that includes each air pollutant that satisfies a three-pronged test. Under the first prong in clause (A), emission of the air pollutant, in the judgment of the EPA Administrator, must "cause or contribute to air pollution which may reasonably be anticipated to endanger public health or welfare." 42 U.S.C. $\$ 7408$ (a)(1)(A) (2006). The language in clause (A) is almost identical to the language in CAA section 202(a)(1), that compelled a finding by a majority of the Supreme Court in Massachusetts that GHG is an air pollutant. See supra notes 24-29 and accompanying text. No rational person could question the second prong in clause (B), that the presence of the air pollutant "results from numerous or diverse" sources, also is satisfied. The third prong, clause (C), requires not only that air quality criteria have not been issued, but also that the Administrator "plans to issue" air quality criteria under section 108. 42 U.S.C. $\S 7408(\mathrm{a})(1)(\mathrm{B})-$ (C) (2006). The Court of Appeals for the Second Circuit, however, has held that clause (C) does not allow EPA discretion not to list pollutants, but was only intended to apply to pollutants EPA already planned to list when the 1970 amendments to the CAA were adopted. Nat. Res. Def. Council v. Train, 545 F.2d 320, 327 (2d Cir. 1976). While EPA may have some discretion under the statutory language, see InIMAI M. CHEETTIAR \& JASON A. SCHWARTZ, THE ROAD AHEAD: EPA'S OPTIONS AND OBLIGATIONS FOR REGULATING GREENHOUSE GASES, NYU SCH. OF LAW, INST. FOR POLICY INTEGRITY REPORT NO. 3, 36 (2009), available at http://www.policyintegrity.org/files/ publications/TheRoadAhead.pdf (arguing that Train may be distinguishable in the case of GHG 
groups filed an administrative petition with EPA in late 2009, arguing that EPA is compelled to adopt national ambient air quality standards for GHGs as a criteria pollutant. ${ }^{156}$

A criteria pollutant listing for GHGs would mean primary and secondary national ambient air quality standards for $\mathrm{GHG}^{157}$ and the attendant revision of state implementation plans to include enforceable GHG emissions limits, control measures, schedules and timetables for compliance, and prohibitions against oil and gas industry emissions sources that contribute to nonattainment of GHG air quality standards ${ }^{168} \mathrm{~A}$ massive new regulatory scheme of target concentrations and related controls would be imposed to control GHGs without any consideration of the cost to industry. ${ }^{159}$ The control regime would be followed by perpetual challenges by environmental groups to the primary and secondary standards for GHGs set by $\mathrm{EPA}^{160}$ and increasingly tighter standards over time.$^{161}$ It is not clear, however, how target concentrations might be set, as GHG concentrations are a global rather than state problem ${ }^{162} \mathrm{EPA}$ itself has hinted that it would consider a national GHG concentration level. ${ }^{163}$

\section{Regulation of Other Pollutants under Varying Thresholds}

If, as the Coalition Court stated, EPA had no choice but to regulate GHGs, then presumably it has the authority to rewrite thresholds applicable

regulation), just as the Supreme Court in Massachusetts forced the Administrator to make a "judgment" on a petition to regulate GHG emissions from automobiles, see supra note 27 and accompanying text, a court (especially a court applying Train) could force a similar judgment by the Administrator as to the regulation of GHG under section 108.

156 See Andrew Childers, Advocacy Groups Ask EPA to Set Standards for Carbon Dioxide, Other Greenhouse Gases, 40 ENV'T REP. (BNA) 2751 (2009).

157 See 42 U.S.C. $\$ 7409$ (2006).

158 See generally, CLEAN AIR ACT HANDBOOK, supra note 47, at 43-78 (summarizing the extensive requirements for approval, implementation, and operation of state implementation plans for criteria pollutants).

159 See Whitman v. Am. Trucking Ass'n, 531 U.S. 457, 471 (2001) (holding that CAA section 109(b) "unambiguously bars cost considerations" by EPA in setting national ambient air quality standards).

160 See ClEAN AIR ACT HANDBOOK, supra note 47, at 20 ("[T] the timing for the reviews has usually been driven by deadline suits brought by environmental organizations.").

161 For example, the primary and secondary standards for ozone have decreased from the 0.08 parts per million standard issued on July 18,1997, to 0.75 parts per million as of March 27, 2008, and EPA currently is considering further reductions. National Ambient Air Quality Standard for Ozone, 43 Fed. Reg. 16,436, 16,437 (Mar. 27. 2008).

162 EPA would have to set atmospheric numerical values that are either above or below present values, meaning that either the entire country would be in nonattainment (creating a massive and costly regime) or the entire country would be in attainment with no realistic expectation of improving atmospheric GHG concentrations. Arnold W. Reitze, Jr., supra note 12, at 914. The prevailing view at EPA and among scholars is that NAAQS is a poor fit for GHG regulation. See, e.g., Nathan Richardson, Greenhouse Gas Regulation under the Clean Air Act: Does Chevron Set the EPA Free?, 29 STAN. EnVTL. L.J. 283, 299 (2010).

163 Regulating Greenhouse Gas Emissions Under the Clean Air Act, Advanced Notice of Proposed Rulemaking, 73 Fed. Reg. 44,354, 44,477-86 (July 30, 2008). 
to other gases present in quantities that were never contemplated for regulation under the CAA. If the thresholds established by EPA for those gases are higher than what is set forth in the express provisions of the CAA, to establish standing a challenger would be forced to argue either that the "endangerment" finding for the gas is arbitrary or capricious, or that the higher threshold subjects the challenger to additional harm from the pollutant itself, but the challenger can never argue both at the same time. Given this catch-22, and the difficultly a party might face in challenging an "endangerment" finding, Coalition provides dangerous precedent for EPA to regulate emissions at whatever levels EPA deems appropriate, despite statutory language to the contrary.

\section{New Source PERformance Standard Regulation of GHG}

\section{A. The Path of New Source Performance Standard (NSPS) Regulation}

New Source Performance Standards (NSPS) are performance standards and work practices applied under CAA section 111 to new, modified and reconstructed sources to reflect the best emissions reduction system achievable that has been adequately demonstrated, taking into account costs; ${ }^{164}$ although, as discussed below, EPA may under certain circumstances apply NSPS to existing sources. ${ }^{165}$ Such standards are specific to categories of sources, not to specific pollutants. ${ }^{166}$ EPA must review and revise standards for already listed categories of sources at least every eight years. ${ }^{167}$

\section{The NSPS Settlement Agreement}

On December 23, 2010, EPA entered into two settlement agreements with Natural Resources Defense Council (NRDC), Sierra Club, Environmental Defense Fund, eleven blue states, the District of Columbia, and the City of New York ${ }^{168}$ under CAA section $111 .{ }^{169}$ One settlement related to both new and existing electric utility steam generating units (EGUs) (i.e., power plants), while the other related to new and existing petroleum refineries. ${ }^{170}$ The EGU settlement required EPA to finalize proposed rules by May 26, 2012, and the refinery settlement required EPA to finalize proposed

\footnotetext{
164 Clean Air Act, 42 U.S.C. $\S 7411$ (a)(1) (2006).

165 See discussion infra Part III.B.4.

166 See Id.

167 See discussion infra Part III.B.3.

168 Settlement Agreement, Dec. 23, 2010, available at http://epa.gov/carbonpollutionstandard/ pdfs/boilerghgsettlement.pdf [hereinafter EGU NSPS Settlement Agreement]; Settlement Agreement, Dec. 23, 2010, available at $\mathrm{http}: / /$ epa.gov/carbonpollutionstandard/pdfs/refineryghg settlement.pdf. [hereinafter Refinery NSPS Settlement Agreement]; see also Energy Bar Ass'n, Report of the Environmental Regulation Committee, 342 ENERGY L.J. 637, 638 (2011).

16942 U.S.C. \& 7411 (2006).

170 EGU NSPS Settlement Agreement, supra note 168; Refinery NSPS Settlement Agreement, supra note 168 .
} 
rules by November $10,2012 .{ }^{171}$ Neither deadline was met. ${ }^{172}$ In response, New York and a number of other states and cities, and three environmental groups filed notices of their intent to sue EPA to compel completion of NSPS for new and existing power plants. ${ }^{173}$

\section{Power Plant GHG New Source Performance Standards}

EPA originally proposed electric utility steam generating unit (EGU) NSPS on April 13, 2012, the first source category-specific NSPS relating to GHG emissions. ${ }^{174}$ The proposed EGU NSPS limits emissions of carbon dioxide $\left(\mathrm{CO}_{2}\right)$ from new fossil fuel-fired power plants that produce greater than twenty-five megawatts (MWs) to 1,000 pounds of $\mathrm{CO}_{2}$ per megawatthour (MWh) of electricity generated on a gross basis. ${ }^{175}$ EPA did not address existing coal-fired power plants or even address modifications to existing plants in the new EGU NSPS, based in the case of modifications on EPA's belief that most new modifications would be pollution control projects. ${ }^{176}$ The failure to address modifications in a NSPS appears to run counter to the express provisions of the CAA. ${ }^{177}$

EPA also did not differentiate between coal-fired and natural gas-fired units in its proposed standards, instead basing emissions limits for both upon the demonstrated performance of existing natural gas combined cycle units, finding that the natural gas combined cycle unit "qualifies as the 'best system of emission reduction' (BSER) that the EPA has determined has been adequately demonstrated..."178 and that "[a]lmost all the stationary

171 EGU NSPS Settlement Agreement, supra note 168 at 3; Refinery NSPS Settlement Agreement, supra note 168 at 4.

172 James E. MCCARTHy, Cong. Research Serv., R41563, Clean AIR ISSUES IN THE 112TH CongRESS 4-5 (2012).

173 See Letter from Eric T. Schneiderman, N.Y. Att'y Gen. et al., to Bob Perciasepe, Acting Admin., Envtl. Prot. Agency, (Apr. 17, 2013), available at http://www.epa.gov/ogc/NOI

documents/StatesNOI_4172013.pdf; Letter from Envtl. Def. Fund, Sierra Club, \& Natural Res. Def. Council, to Bob Perciasepe, Acting Admin., Envtl. Prot. Agency, (Apr. 15, 2013), available at http://www.epa.gov/ogc/NOIdocuments/EnvNOIApr152013.pdf.

174 Standards of Performance for Greenhouse Gas Emissions for New Stationary Sources: Electric Utility Generating Units, 77 Fed. Reg. 22,392 (Apr. 13, 2012) [hereinafter Proposed Power Plant NSPS].

175 Id.

176 Id. at $22,400,22,421$.

177 See Clean Air Act, 42 U.S.C. $\$ 7411$ (2006) (defining "new source" as "any stationary source, the construction or modification of which is commenced after publication of regulations (or, if earlier, proposed regulations) prescribing a standard of performance under this section which will be applicable to such source.")(emphasis added); see also Arnold W. Reitze, Jr., Comment: EPA's Proposed New Source Performance Standards to Control Greenhouse Gas Emissions from Electric Utility-Generating Units, 42 ENVTL. L. REP. NEws \& ANALYSIS 10606, 10609 (2012) (arguing that the failure to include modifications is a violation of CAA section 111(a)(2)).

178 Proposed Power Plant NSPS, supra note 174. at 22,394. 
combined cycle gas turbines built in the U.S. in the last five years can meet the proposed standard of $1,000 \mathrm{lb} \mathrm{CO} / \mathrm{MWh}^{\text {"179 }}$

A new coal plant may still be an option under the proposed rule if the new plant installs carbon capture and sequestration (CCS) technology to limit $\mathrm{CO}_{2}$ emissions $\mathrm{MWh}$ to levels similar to or lower than those of natural gas units without CCS. ${ }^{180}$ The proposed rule does allow an alternative CCS compliance pathway for new coal-fired generation without CCS at a limit of 1,800 pounds of $\mathrm{CO}_{2} / \mathrm{MWh}$ if: 1) the EGU is designed to allow for installation of operation of CCS; 2) CCS is installed in the 11th year of operation; and 3) the owner or operator commits to enforceable limits of 600 pounds of $\mathrm{CO} / \mathrm{MWh}$ after the installation of $\mathrm{CCS}$, and 1,000 pounds of $\mathrm{CO}_{2} / \mathrm{MWh}$ averaged over a thirty year period. ${ }^{181}$ Transitional sources with complete Prevention of Significant Deterioration air construction permits received before April 13, 2012, are exempt from the proposed rule if construction is completed by April 13, 2013. ${ }^{182}$

As of the writing of this article, it is unclear what the final rule for new power plants or the proposed rule for existing power plants ultimately will mandate. On June 25, 2013, in a speech at Georgetown University garnering significant media attention, President Obama introduced his new climate change plan, featuring power plant NSPS as the centerpiece for climate change action. ${ }^{183}$ A few days later, on July 1, 2013, EPA sent a confidential revised rule to the White House Office of Management and Budget that some insiders report may establish separate standards for coal- and natural gasfired units, apparently in attempt to address some of the more than two million public comments to the proposed NSPS for new power plants. ${ }^{184}$ Under his new plan, the President issued a memorandum giving EPA until September 20, 2013 to complete a revised draft of the rewritten rule for new power plants, and until June 1, 2014 to propose a rule for modified, reconstructed, and existing plants, with a final rule due by June 1,2015 , and implementing regulations to be drafted by states due by June $30,2016{ }^{185}$

179 Id. at $22,396$.

180 Id. EPA expects that the costs of CCS will decline in the future as CCS matures and is utilized more widely. In fact, EPA's modeling projects that there will be no construction of new coal-fired generation without CCS by 2030 . Id. at 22,395. Query whether this prophesy is based on markets or policy.

181 Id. at 22,436 .

182 Id

183 The White House, President Obama Speaks on' Climate Change, http://www.white house.gov/photos-and-video/video/2013/06/25/president-obama-speaks-climate-change (last visited July 21, 2013); see also Executive OfFICE of THE PREsident, THE President's Climate ACTION PLAN (2013), available at http://www.whitehouse.gov/sites/default/files/image/pres ident27sclimateactionplan.pdf [hereinafter, CLIMATE ACTION PLAN]; Johnson, Fowler, and Sweet, supra note 10.

- 184 Zack Colman, EPA Sends White House Revised Emissions Rule for New Power Plants, THE HIL E ${ }^{2}$ WIRE (July 1, 2013), available at http://thehill.com/blogs/e2-wire/e2-wire/308737revised-emissions-rule-for-new-power-plants-heads-to-white-house (last visited July 21, 2013).

185 Barack Obama, PREsidential Memorandum-Power Sector Carbon Pollution STANDARDS June 25, 2013, available at http://www.whitehouse.gov/the-press-office/2013/06/25/ 
Even though these dates are much later than originally promised by EPA, states and environmental groups pushing for changes have delayed their promised lawsuits against EPA in response to the President's plan. ${ }^{188}$

\section{B. Implications of NSPS GHG Regulation for the Oil and Gas Industry}

\section{Implications of New and Existing Power Plant NSPS and the Promise of Cheap Natural Gas}

If the NSPS for new, modified, and existing power plants ultimately ban or severely limit the use of coal for electricity generation, the price of natural gas will rise, encouraging natural gas exploration and production, but at a cost to electricity consumers, especially if the rules already proposed by EPA for new plants continue to strongly favor natural gas and extend similar standards to modified and existing plants. ${ }^{187}$ Endorsing the power industry's recent propensity to retire coal-fired plants in favor of lowcost natural gas, ${ }^{188}$ EPA stated in its adopting release for the proposed rule for new plants that it "does not anticipate that this proposed rule will result in notable $\mathrm{CO}_{2}$ emission changes, energy impacts, monetized benefits, costs,

presidential-memorandum-power-sector-carbon-pollution-standards

186 See Jessica Coomes \& Anthony Adragna, New York, Environmental Groups to Delay Lawsuits to Force Action on Power Plants, BloomBERg BNA (June 18, 2013), http://www.bna.com/new-york-environmental-n17179874676/ (last visited July 21, 2013). New York Attorney General Schnedierman and several of the environmental groups that previously threatened suit issued press releases after the President's speech praising his climate change action plan, indicating that the President successfully bought additional time for EPA to develop its new rules. See, e.g., Press Release, N.Y. Att'y Gen. Eric T. Schneiderman, Statement from A.G. Schneiderman On President Obama's Plan to Fight Climate Change (June 25, 2013), available at http://www.ag.ny.gov/press-release/statement-ag-schneiderman-president-obamasplan-fight-climate-change; Press Release, Sierra Club, Sierra Club Statement on President Obama's Climate Plan (June 25, 2013), available at http://content.sierraclub.org/pressreleases/2013/06/sierra-club-statement-president-obama\%E2\%80\%99s-climate-plan.

187 EPA's intentions as to its revised standards for new power plants are short on details, but environmental groups are resisting the idea that EPA would weaken its proposal. See Jean Chemick, Obama Indicates EPA Will Revise Its Pending Rule for Future Power Plants, E\&E PUBLISHING LLC, (June 26, 2013) available at http://www.eenews.net/eedaily/stories/1059983481 (last visited July 21, 2013) (quoting David Hawkins, Nat. Resources Def. Council President "Taking more comment on the New Source Performance Standard doesn't imply weakening it.").

188 The coal mining industry was not pleased with the preference for natural gas in the Proposed Power Plant NSPS. See Chris Hamby, EPA Proposes First Limit on Greenhouse Gases, CENTER FOR PUBLIC INTEGRITY, (Mar. 27, 2012), http://www.publicintegrity. org/2012/03/27/8521/epa-proposes-first-limit-greenhouse-gases (last visited July 21, 2013) (quoting American Coalition for Clean Coal Electricity: “Unfortunately, the EPA continues to ignore the real impact their rules will have on American fanilies and businesses by driving up energy prices and destroying jobs...."). See also Manuel Quinones, Duke Accelerates N.C. Plant Retirements, E\&E PUBLISHING LLC, (Feb. 1, 2013), http://www.eenews.net/eenewspm/ 2013/02/01/archive/8?terms=Duke+accelerates (last visited July 21, 2013) (announcing the accelerated retirement of two coal fired power plants. Duke officials cited low natural gas prices as one of the reasons for an earlier closure). 
or economic impacts by $2020 \ldots$.." or "have any impacts on the price of electricity, employment or labor markets, or the US economy. ${ }^{1180}$ Such a prediction of no price increases is bold and may fail to consider the numerous factors that will affect future demand for natural gas in the United States.

The prolific supply of natural gas from the recent United States shale production boom has kept natural gas prices low, so low in fact that some manufacturers are deciding to site new plants in the United States because the cost-benefit of inexpensive natural gas in the United States outweighs the cost-benefit of inexpensive labor in Asia. ${ }^{190}$ If natural gas prices stay consistent with current prices or rise at low levels, one could see how EPA could predict no economic impacts. It seems likely, however, that demand pressures on natural gas from redomesticated manufacturing and increased usage as a feedstock fuel for electricity under EPA rules will correspond with at least some additional demand pressures from exports. ${ }^{191}$

Shale gas that is not liquefied for transport is effectively trapped in North America, ${ }^{192}$ keeping domestic prices low, but also resulting in large price differentials between gas in the United States and gas in other markets, spurring intense interest in exporting liquefied natural gas (LNG), especially to Asian markets where such exports would undercut prevailing oil-indexed supplies. ${ }^{193}$ Some industrial consumers of gas in the United States have taken the position that the United States Department of Energy (DOE) should block LNG exports to limit demand for natural gas. ${ }^{184}$ Studies analyzing the

189 Proposed Power Plant NSPS, supra note 174 at 22,430.

190 See John W. Miller, Cheaper Natural Gas Lets Nucor Factory Rise Again on Bayou, WALL ST. J., Feb. 1, 2013, at Bl, available at http://online.wsj.com/article/SB100014241278

87323854904578264080157966810.html ("Chemical and fertilizer companies, which use gas as both a feedstock and energy source, say lower prices have reduced.costs and made the U.S. a more competitive manufacturing location.").

191 See, e.g., Mark Green, Natural Gas Exports for U.S. Jobs, Growth, and Trade, THE ENERGY COLLECTIVE (Jan. 27, 2013), http://theenergycollective.com/mark-green/177261/lngexports-us-jobs-economic-growth-trade (last visited July 21, 2013).

192 In 2012, the U.S. exported a total of 1,618,946 million cubic feet of natural gas, 1,590,648 of which was exported by pipeline to Canada and Mexico. See U.S. Energy Info. Admin., U.S. Natural Gas Exports by Country, http:/www.eia.gov/dnav/ng/ng_move_expc_s1_a.htm (last visited July 21, 2013).

193 IEA REPORT, supra note 1, at 129. In June 2012, spot gas was trading at as low as $\$ 2.10$ per million British thermal unit (MBtu) at the U.S. Henry Hub compared to \$17.40/MBtu for spot LNG in northeast Asia. Id. See also Damon Evans, IEA Puts Weight Behind Asian Gas Spot Market, PETROLEUM ECONOMIST (Oct. 23, 2012), http://www.petroleum-economist.com/Article/ 3107199/IEA-puts-weight-behind-Asian-gas-spot-market.html (last visited July 21, 2013) (discussing problems with oil-indexed supplies in Asia).

194 The U.S. Department of Energy (DOE) regulates international trade in natural gas under the Natural Gas Act 15 U.S.C. $\S 717 \mathrm{~b}$ (2006), and is required to approve applications for trade with LNG Free Trade Agreement nations and other nations unless it finds for such other nations that exports would not be consistent with the "public interest." See Sean Dixon, Liquefied Natural Gas Exports and Export Facilities: A Statutory Framework, TRENDS, July 2012. The Federal Energy Regulatory Commission (FERC) permits the siting, construction, and operation of onshore LNG terminals and pipelines, and has received a number of proposals for LNG export authority. See Hong N. Huynh, The U.S. Race to Export LNG, NAT. RESOURCES \& ENV., 
price impact of LNG exports have been somewhat mixed, but generally support the conclusion that exporting LNG alone should not have a significant impact on the domestic price of natural gas. ${ }^{195}$ While DOE to date has approved very few LNG export applications to countries that are not a party to a free-trade agreement with the United States, ${ }^{196}$ the expansion of exports seems inevitable based on pressure from the natural gas industry, support from bipartisan members of Congress, ${ }^{197}$ and the President's recent call in his climate plan for greater international use of natural gas. ${ }^{198}$

Fall 2012, at 1. Flooded with new export applications, DOE prepared an export study and solicited comments on the study "to ensure that authorizations to export LNG do not subsequently lead to a reduction in the supply of natural gas needed to meet essential domestic needs." 2012 LNG Export Study, 77 Fed. Reg. 73,627, 73,628 (Dec. 11, 2012) (requests for comments). Large manufacturers that use significant amounts of natural gas have objected to such exports. See, e.g., Hannah Northey, Dow Leaves Trade Group In Dispute Over LNG Exports, E\&E PUBLISHING LLC (Jan. 22, 2013), available at http://www.eenews. net/greenwire/2013/01/22/stories/1059975109 (last visited July 21, 2013). IEA for their part projects that $93 \%$ of natural gas produced in the United States will remain available to meet domestic demand and that exports will not play a large role in domestic pricing. IEA REPORT, supra note 1 , at 129 . However, even a $7 \%$ drop in available domestic natural gas production could severely impact electricity prices in a market where the use of natural gas is mandated as the primary fuel for electricity generation. See generally U.S. DEP'T OF ENERGY, NATURAL GAS AND ELECTRICITY COSTS AND IMPACTS ON INDUSTRY 1 (2008) (addressing high demand of LNG and the correlation between a shortage of its availability and increased electricity costs).

195 In the LNG export study commissioned by DOE, NERA Economic Consulting estimated wellhead natural gas price increases, but a small net positive impact of exports to the United States economy. NERA ECON. CONSULTING, MACROECONOMIC IMPACTS OF LNG EXPORTS FROM THE UNITED STATES 48-49 (2012), available at http://www.fossil.energy.gov/programs/gasregulation /reports/nera_lng_report.pdf [hereinafter NERA REPORT]. In contrast, a more recent study from Purdue University predicted higher price increases under comparable scenarios and a small net negative impact on the economy, with the burden of higher natural gas and electricity prices falling on U.S. consumers. See WALLACE TyNer \& KEMAL SARICA, COMPARISON OF ANALYSIS OF NATURAL GAS EXPORT IMPACTS FROM STUdiES DONE BY NERA ECONOMIC CONSUlTANTS AND PURDUE UNIVERSITY 3 (2013), available at $\mathrm{http} / /$ www.fossil.energy.gov/programs/gasregulation /authorizations/export_study/30_Wallace_Tyner01_14_13.pdf [hereinafter PURDUE STUDY]. An even more recent study concluded that LNG exports are unlikely to have any large impact on domestic natural gas prices due to the vast supply of U.S. natural gas reserves and the capital costs associated with transportation and liquefaction of LNG, finding instead that domestic gas prices are more likely to influence exports than the other way around. BIPARTISAN POL'Y CTR., NEW DYNAMICS OF THE U.S. NATURAL GAS MARKET 31 (May 2013).

196 DOE issued its first non-free trade agreement export authorization to Sabine Pass Liquefaction LLC in a series of orders beginning. in 2011, Sabine Pass Liquefaction LLC, FE Docket No. 10-111-LNG, DOE/FE Order No. 2961 (May 20, 2011), reh'g denied, DOE/FE Order No. 2961-A (Aug. 7, 2012), reh'g denied, DOE/FE Order No. 2961-B (Jan. 25, 2013), and its second non-free trade agreement export authorization to Freeport LNG Expansion LP and FLNG Liquefaction LLC on May 17, 2013. Freeport LNG Expansion LP, FE Docket No. 10-161 LNG, DOE/FE Order No. 3282 (May 17, 2013).

197 See Hannah Northery, Industry Group Fights Bipartisan Push For LNG Exports, E\&E PUBLISHING, LLC (Feb. 6, 2013), http://www.eenews.net/Greenwire/2013/02/06/archive 18?terms=bipartisan+push+LNG+exports (last visited July 21, 2013) (discussing opposition of the American Public Gas Association to a bipartisan Senate bill and a House Republican measure that would amend laws to require the DOE to approve export applications).

198 CLIMATE ACTION PLAN, supra note 183 at 19. 
Reflecting these new demands for natural gas, the IEA, in its World Energy Outlook 2012, predicts that natural gas is the only fossil fuel that will see demand increases under all of its scenarios, from 3.4 trillion cubic meters in 2011 to just fewer than 5 trillion cubic meters in 2035 under its base scenario. ${ }^{199}$ Such predictions assume natural gas prices rise from the historical lows seen in 2011-2012, but "at levels that promote a continued expansion of consumption (including the envisaged start of liquefied natural gas [LNG] exports)." ${ }^{200}$ IEA's 2012 predictions also assume, however, that coal will remain the largest source of fuel for electricity generation in the United States in $2035^{201}$ and that the extent to which gas is used for electricity generation in the United States will "depend critically on the price of the fuel (taking account of any carbon penalties), both in absolute terms and relative to the price of coal...."202 One LNG study goes further, predicting in light of increased natural gas prices from exports that domestic use of coal will increase from $21 \%$ to $23 \%$ of the United States energy mix by $2035 .^{203}$

Despite these predictions, however, coal cannot remain the largest primary fuel source for electricity generation and certainly cannot increase as a percentage of the United States energy mix unless either: 1) provisions contained in anticipated standards for new and existing electric utility generating units allow for the continued dominance of coal, a prospect environmental groups would be loath to accept; or 2) CCS technology becomes commercially available relatively quickly, which seems highly unlikely, ${ }^{204}$ notwithstanding the Administration's recent efforts to promote CCS. $^{205}$

199 IEA REPORT, supranote 1, at 126.

200 Id. at 127.

201 Id. at 197. While coal is predicted to remain the largest fuel source for electricity, IEA also predicts under its base scenario that gas-fired electricity generation increases by over 360 terawatt hours. Id.

202 Id. at 132.

203 PURDUE STUDY, supra note 195, at 3.

204 Björn Nykvist, Ten Times More Difficult: Quantifying the Carbon Capture and Storage Challenge, ENERGY POL'y, Apr. 2013, at 683, 688 ("CCS might have an important role as a low carbon technology in the long term, but expectations for contributions in the coming 10-20 years envisioned by some actors are currently far higher than what developments to date can support.”); Letter from Hal Quinn, President \& CEO, Nat'l Mining Ass'n, to Congressman Henry A. Waxman and Sen. Sheldon Whitehouse 5 (Mar. 12, 2013), available at http://www. nua.org/attachments/article/680/Waxman-Whitehouse\%20Letter\%203-12-13.pdf ("[CCS] will cost significantly more than conventional technology and will require extended lead time.").

205 As part of the President's climate action plan, see ClimATE ACTION PLAN, supra note 183, at 7, on July 2, 2013, the U.S. Department of Energy released a draft solicitation announcement under Title XVI of the Energy Policy Act of 2005 to solicit applications for up to $\$ 8$ billion in loan guarantees for advanced fossil energy projects, including "[p]rojects or facilities that integrate fossil fuel usage in traditional processes with new or improved technology that captures and removes $\mathrm{CO}_{2}$ for permanent storage in underground formations or through beneficial reuse"). U.S. DEP'T OF ENERGY, DRAFT LOAN GUARANTEE SOLICITATION ANNOUNCEMENT 2 (2013), available at $\mathrm{http} / / /$ po.energy.gov/resource-library/solicitations/advanced-fossilenergyprojects-solicitations/. 
Natural gas and coal are substitutes for electricity generation that effectively temper the price of both. Rising natural gas prices tend to push electricity generators to switch back to coal, ${ }^{208}$ thereby reducing the demand for gas and discouraging production, especially for operators that may choose to produce oil instead at a higher profit. ${ }^{207}$ If law mandates dramatically less domestic coal usage, the demand for natural gas and the related price will naturally rise faster, especially when combined with LNG exports. ${ }^{208}$ Such a rise in price would encourage domestic natural gas production in a manner consistent with the President's stated climate and energy plans, ${ }^{209}$ but it would also increase the electricity price to the consumer. A high enough natural gas price in the absence of coal as a legal substitute could also incentivize other climate-friendly behavior by utilities, causing renewable energy to suddenly become a more affordable alternative for electricity generation, a prospect made even more likely if the President implements the proposals in his plan that benefit renewables. ${ }^{210}$

\section{Refinery New Source Performance Standards}

GHG NSPS for the refining industry have not been finalized or even proposed as required by the NSPS settlement agreement relating to refineries. ${ }^{211}$ NSPS regulations-and amendments to existing regulationsfor petroleum refineries ${ }^{212}$ have been the subject of ongoing rulemakings from May 14, 2007, through September 12, 2012, but when the standards eventually were finalized, the final rules did not contain GHG emissions standards for refineries or even mention GHGs. ${ }^{213}$ Delayed by the election

206 See U.S. Energy Info. Admin., Year-to-Date Natural Gas Use for Electric Power Generation is Down from 2012, Apr. 11, 2013, http://www.eia.gov/todayinenergy/ detail.cfm?id=10771 (last visited July 21, 2013) (coal recovered marketed share in 2013 compared to 2012 as natural gas prices rose).

207 See Liam Denning, A Shale Tale: Natural Gas Will Pay the Price for OWn Success, WaLl ST. J., June 10, 2013, at C.6, available at http://online.wsj.com/article/SB10001424127887 324069104578531554164400008.html (exploration and production investment dollars flowing mostly toward oil with high oil prices and low natural gas prices).

208 See NERA REPORT, supra note 195, at 25 ("The shift toward natural gas could be accelerated by pending and possible future air, water, and waste regulations and climate change policies. Thus the potential exists for significant increases in natural gas demand across the U.S. economy.").

209 See Kevin Begos, Obama's Natural-Gas Stance Criticized (July 5, 2013), AssocLATED PRESS, http://www.abqjournal.com/main/217723/biz/obamas-naturalgas-stance-criti cized.html (last visited July 21, 2013) (discussing praise by Obama in climate change address for "cleaner-burning natural gas").

210 See CLIMATE ACTION PLAN, supra note 183, at 7 (accelerating renewable permitting on public lands); $i d$. at 20 (calling for the end of fossil fuel tax subsidies in 2014 budget).

211 See supra notes 168-173 and accompanying text.

212 Standards of Performance for Petroleum Refineries, 40 C.F.R. $\S \S 60.100-60.108$ (2012); Standards of Performance for Petroleum Refineries for Which Construction, Reconstruction, or Modification Commenced After May 14, 2007, 40 C.F.R. $\$ \S 60.100 a-60.109$ a (2012).

213 See Standards of Performance for Petroleum Refineries, 72 Fed. Reg. 27,178 (May 14, 2007 ) (codified at 40 C.F.R. pt. 60); Standards of Performance for Petroleum Refineries, 73 Fed. 
and by the pending rules for power plants, which have been a greater priority for environmental groups, discussions with EPA regarding the new refinery rules may not begin again until the Obama Administration completes rules for existing power plants in 2015. ${ }^{214}$ Petroleum refiners should not be lulled into believing that either EPA or environmental groups will somehow forget about them, but should begin using the additional time to plan their response and consider reasonable technologies and efficiency measures in light of alternatives.

\section{Future Regulation of Midstream and Upstream Oil and Gas and Operations under NSPS}

Following the adoption of rules for power plants and then refineries, it may only be a matter of time before upstream and midstream oil and gas operations are also subject to GHG-specific NSPS The upstream oil and gas industry joined the ranks of power plants, refineries, steel plants, and other listed source categories regulated under NSPS when new rules were finalized on August 16, 2012. ${ }^{215}$ These new rules require, inter alia, controls for emissions from storage tanks and compressors, and beginning in 2015, will require green completions that eliminate flaring of most gas wells during hydraulic fracturing flowback operations. ${ }^{216}$ Although the Oil and Gas NSPS apparently were crafted to address emissions of volatile organic compounds and air toxics, EPA touted the co-benefit of the rule as providing reduced GHG emissions of methane. ${ }^{217}$

Reg. 35,838 (June 24, 2008) (codified at 40 C.F.R. pt. 60); Standards of Performance for Petroleum Refineries, 73 Fed. Reg. 43,626 (July 28, 2008); Standards of Performance for Petroleum Refineries, 73 Fed. Reg. 55,751 (Sept. 26, 2008); Standards of Performance for Petroleum Refineries for Which Construction, Reconstruction, or Modification Commenced After May 14, 2007, 73 Fed. Reg. 78,522 (Dec. 22, 2008) (codified at 48 C.F.R. pt. 60); Standards of Performance for Petroleum Refineries for Which Construction, Reconstruction, or Modification Commenced After May 14, 2007, 73 Fed. Reg. 78,546 (Dec. 22, 2008); Standards of Performance for Petroleum Refineries for Which Construction, Reconstruction, or Modification Commenced After May 14, 2007, 77 Fed. Reg. 56,422 (Sept. 12, 2012) (codified at 48 C.F.R. pt. $60)$.

214 In late 2012, some environmental groups believed talks would resume in 2013, see Andrew Childers, Resumption of Talks Expected in January on Refinery Greenhouse Gas Rule Deadline, BNA BLOOMBERG (Dec. 7, 2012), http://www.bna.com/resumption-talks-expectedn17179871297/ (last visited July 21, 2013) (quoting Eric Schaeffer, Exec. Dir., Envtl. Integrity Project), but rules for refineries were not even mentioned in the President's new climate change action plan. See generally, CLIMATE ACTION PLAN, supra note 183.

215 Oil and Natural Gas Sector: New Source Performance Standards and National Emissions Standards for Hazardous Air Pollutants Reviews (Final Rule), 77 Fed. Reg. 49,490 (Aug. 16, 2012) (to be codified at 40 C.F.R. pt. 60 \& 63).

216 See id. at 49,490, 49,497.

217 See Press Release, EPA, EPA Issues Updated, Achievable Air Pollution Standards for Oil and Natural Gas / Half of Fractured Wells Already Deploy Technologies in Line with Final Standards, Which Slash Harmful Emissions While Reducing Cost of Compliance (Apr. 18, 2012), available at http://yosemite.epa.gov/opa/admpress.nsf/79c090e81f0578738525781f0043619b/c742 df7944b37c50852579e400594f8f!OpenDocument. 
EPA must periodically review NSPS for listed categories "at least every eight years" and revise those standards "if appropriate," unless EPA determines that such a review is "not appropriate." ${ }^{218}$ Although EPA has argued that it has discretion as to what is "appropriate," argued that the word "appropriate" does not make revisions optional to include GHG standards for existing categories. ${ }^{20}$ Backed by such scholarship, a seven state coalition of Northeastern States led by New York Attorney General Eric T. Schneiderman recently gave notice to EPA that it intends to sue EPA to compel it to revisit the recently effective NSPS for the oil and gas industry to include standards of performance for methane emissions. ${ }^{221}$ Oklahoma and twelve other producing states argue that EPA should not negotiate with the Northeastern states, and if they do, that the producing states should have the right to participate. ${ }^{222}$ Whether EPA decides to take sides with the Northeastern States, or to include all interested states in the negotiations, will likely impact the timing and extent of future GHG NSPS for the oil and gas production industry.

\section{Regulation of Existing Sources under NSPS?}

One of the most frequently cited flaws of the CAA in general and NSPS in particular is the emphasis on new or modified sources based on the presumption that old facilities would eventually be retired and replaced by newer facilities subject to the standards. ${ }^{223}$ As described above, however, EPA has agreed in legal settlements to regulate GHG emissions from existing power plants and refineries; in the case of power plants, such regulation

218 Clean Air Act, 42 U.S.C. $\$ 7411$ (b)(1)(B) (2006).

219 See Standards of Performance for Petroleum Refineries, 73 Fed. Reg. 35,838, 35,858 (June 24, 2008) (codified at 40 C.F.R. pt. 60) (arguing in defense of not establishing GHG performance standards for refineries that EPA has always interpreted CAA section 111(b)(1)(B) as providing significant flexibility in determining which pollutants are appropriate for regulation under that section).

220 Inimai M. ChetTlar \& JASON A Schwartz, The RoAD AHEAD: EPA's Options AND OBLIGATIONS FOR REgULATING GREENHOUSE GASES 50-51 (2009), available at http://policyintegrity.org/publications/detail/the-road-ahead. In the view of Chettiar and Schwartz, EPA also has an obligation to list new categories of sources of GHG emissions under CAA section 111(b)(1)(B) with a finding that a source "contributes significantly" to GHG air pollution, and that while EPA has some discretion as to the timing of such a new listing, it could be forced by one or more states to make a listing determination for a new category within three months. Id. at $48-49$.

221 Letter from Eric T. Schneiderman, N.Y. Att'y Gen., to Lisa P. Jackson, Adm'r, U.S. Envtl. Prot. Agency, (Dec. 11. 2012), available at http://www.ag.ny.gov/pdfs/ltr_NSPS_Methane_ Notice.pdf.

222 Letter from E. Scott Pruitt, Okla. Att'y Gen., to Acting Adm'r, Bob Perciasepe, and Gina McCarthy, Assistant Adm'r, U.S. Envtl. Prot. Agency, (May 2, 2013), available at http:/www.oag.ok.gov/oagweb.nsf/3e67f1cee13bc090862572b2005ad559/23b407a5f6b513188625 7b600077acf1/\$FILE/FINAL\%20-\%20EPAMethane050213.pdf.

223 See, e.g., Robert R. Nordhaus, Modemizing the Clean Air Act: Is There Life After 40?, 33 ENERGY L. J. 365, 373 (2012). 
being a key component of the President's climate change strategy. ${ }^{224}$ To accomplish this new regime, environmental groups and some scholars have proposed the application of a rarely used provision of the CAA, section $111(d){ }^{225}$ for controlling existing sources of GHG emissions whether or not such sources have been modified. ${ }^{226}$ When section $111(\mathrm{~d})$ applies, EPA issues guidelines that must be followed by states that in turn develop regulations to control existing-rather than new, modífied, or reconstructed-sources of air pollution. ${ }^{227}$ The question then becomes when section 111(d) applies.

Under section $111(\mathrm{~d})$, the Administrator shall prescribe regulations that establish standards of performance for existing sources in a source category when 1) EPA has promulgated NSPS for new sources in the category, 2) the air pollutant covered by the NSPS is not a criteria pollutant, and 3) the air pollutant is "not . . . emitted from a source category which is regulated under [CAA section 112]." ${ }^{228}$ Given that GHG is not, at least for now, a criteria pollutant, is EPA then bound to establish standards for existing power plants or existing refineries, as applicable, after EPA establishes standards for new power plants or refineries, respectively. ${ }^{229}$

The answer seems to hinge on the third element. CAA section 112 relates to hazardous air pollutants - the.category of the most dangerous pollutants-but all categories of major sources in the power plant and oil and gas industries already are regulated under section $112 .{ }^{230}$ Accordingly, GHG is emitted from a source category that is regulated under section 112 .

Although that would seem to be the end of the argument, ${ }^{231}$ many scholars and environmental groups have argued that the third requirement under section 111 (d) actually means that the air pollutant itself is not regulated as a hazardous air pollutant. The argument follows that because GHG is not such a pollutant, whenever EPA regulates a source category such as power plants under NSPS for new sources, it should be required to limit emissions from existing sources in the same source category. ${ }^{232}$ To date, EPA

224 See supra notes 170,183 and accompanying text.

225 Clean Air Act, 42 U.S.C. $\$ 7411$ (d) (2006).

226 See ChETTLAR \& SCHWARTZ, supra note 220, at 52; NAT'L RES. DEF. COUNCIL (NRDC), USING the Clean air act to Sharply Reduce Carbon Polluttion from Existing Power Plants, Creating Clean Energy Jobs, Improving Americans' Health, and Curbing Cuimate Change 2 (2012), available at http://www.nrdc.org/air/pollution-standards/.

22742 U.S.C. $\$ 7411$ (d) (2006).

228 Id. $\$ 7411(\mathrm{~d})(1)(\mathrm{A})$.

229 See supra Parts III.A.2, III.B.2.

23042 U.S.C. $\$ 7412$ (c) (2006); Regulating Greenhouse Gas Emissions Under the Clean Air Act, 73 Fed. Reg. 44,354, 44,494 (July 30, 2008).

231 In a recent interview, former EPA Administrator, Roger Martella, made this same argument, also pointing out that "my colleagues at EPA vehemently disagree with me on that, and they have disagreed with me on that, but nonetheless, I think my reading and the reading of some others is the much clearer interpretation of the statute, if you just open it up and look at it." Interview by Monica Trauzzi of Roger Martella, Former Gen. Counsel EPA (Mar. 20, 2013), available at $\mathrm{http}: / / \mathrm{www}$.eenews.net/eenewspm/2013/03/20/13.

232 See CHETTIAR \& SCHWARTZ, supra note 220, at 52; WANNIER ET AL., PREVAILING ACADEMIC VIEW ON COMPLIANCE FLEXIBILITY UNDER $\$ 111$ of THE CleAN AIR ACT 15, n.5 (2011), available at 
has only used section 111 (d) for specialized types of emission sources that emit discrete types of pollutants. ${ }^{233}$ Both the power plant EGU settlement and the refinery settlement did, however, specifically reference section $111(d){ }^{234}$

We will have to wait to see whether and how EPA might apply section 111(d) to create performance standards for existing sources of GHG, but environmental groups are not likely to back down. When NSPS for new or modified power plants were proposed, environmental groups clearly were upset that EPA had not addressed existing sources of GHG emissions from EGUs under CAA section 111 (d) in the proposed rule. ${ }^{235}$ The NRDC has proposed a flexible program for power plants that allows for a variety of options, but also requires a $26 \%$ reduction in GHG emissions by 2020 and a $34 \%$ reduction by 2025 . $^{236}$

NSPS for existing sources would be particularly expensive for refineries, one of the most complex and highly-regulated major sources in the United States. Natural gas compression, dehydration, and other processing plants could also represent a significant category of existing sources should section 111 (d) be extended to the oil and gas industry segment.

Some scholars and environmental groups also have argued that section 111(d) is sufficiently flexible to mandate national requirements for state-run market-based programs such as cap-and-trade programs. ${ }^{237}$ Section $111(\mathrm{~d})$ provides that the Administrator has the same authority to establish procedures similar to that provided by section 110 , for state implementation plans for criteria pollutants, which expressly provides for plans that include "emission limitations and other control measures, means, or techniques (including economic incentives such as fees, marketable permits, and auctions of emissions rights)...."238 Note that if EPA were to attempt to regulate existing sources through state-mandated cap-and-trade programs, such federally mandated programs could conflict with existing state programs such as the new California cap-and-trade program. ${ }^{239}$

http://www.rff.org/RFF/Documents/RFF-DP-11-29.pdf; NRDC, supra note 226, at 2.

233 See ClEAN AIR ACT HANDBOOK, supra note 47, at 331.

234 EGU NSPS Settlement Agreement, supra note 168, at 3; Refinery NSPS Settlement Agreement, supra note 168, at 3.

235 See, e.g., Felicity Barringer, For New Generation of Power Plants, a New Emission Rule from the E.P.A, N.Y. TiMES, Mar. 27, 2012, http://www.nytimes.com/2012/03/28/science/earth /epa-sets-greenhouse-emission-limits-on-new-power-plants.html (last visited July 21, 2013) (quoting Frances Beinecke, NRDC President, "The logical next step is to improve the aging fleet of existing coal-fired power plants, which remain the major source of industrial carbon pollution in our country.").

236 Daniel A. Lashof et al., Natural Res. Def. Council, Closing the Power Plant Carbon Pollution loophole: Smart Ways the Clean AIR ACT CAN Clean UP AMERICA'S Biggest ClmMATE POLLUTERS 5 (2012), available at http://www.nrdc.org/air/pollution-standards /files/pollution-standards-report.pdf.

237 See generally WANNIER ET. AL., supra note 232; NRDC, supra note 226, at 2.

238 Clean Air Act, 42 U.S.C. $\$ 7410$ (a)(2) (2006) (emphasis added).

239 See ClEAN AIR ACT HANDBOOK, supra note 47, at 537-38. 


\section{Federal Market-Based Regulation of GHG}

\section{A. The Path of [No] Cap and Trade in the U.S.}

\section{Climate Change Legislation}

Climate change has been a hot topic for Congress in recent years. Legislation addressing the wide-ranging topic, however, has been varied and largely unsuccessful. ${ }^{240}$ With the election of President Barack Obama in 2008, hopes were high that the 111th Congress could pass some form of climate legislation. Over 250 bills, resolutions, and amendments related to climate change were introduced in the 111th Congress, most of which never made it out of committee. ${ }^{241}$

The major exception was the American Clean Energy and Security Act of 2009, H.R. 2454, otherwise known as ACES or the Waxman-Markey Bill (Waxman-Markey). ${ }^{242}$ Among many other different and complex provisions, Titles III and V of Waxman-Markey contained a GHG cap-and-trade program that would cover, among others, stationary sources emitting more than 25,000 tons of GHGs per year; producers and importers of petroleum fuels; and distributors of natural gas. ${ }^{243}$ The bill set emission caps reducing aggregate GHG emissions for all covered entities to $3 \%$ below their 2005 levels in 2012; 17\% below 2005 levels in 2020; $42 \%$ below 2005 levels in 2030; and $83 \%$ below 2005 levels in $2050 .^{244}$ Waxman-Markey also contained allowance and offset provisions in an attempt to contain costs to consumers and businesses. ${ }^{245}$ It required state trading systems to be put on hold from 2012-2017, but allowed entities holding allowances issued by California, the

240 ' See generally Ctr. For Climate Change and Energy Solutions, Bills of the 111th Congress Concerning Climate Change, http://www.c2es.org/federal/congress/111/climate-change-legislati ve-proposals (last visited July 21, 2013) [hereinafter C2ES 111th Bills]; Ctr. For Climate Change and Energy Solutions, Bills of the 112th Congress Concerning Climate Change, http://www.c2es.org/federal/congress/112/climate-change-legislative-proposals (last visited July $21,2013)$ [hereinafter C2ES 112th Bills].

241 See C2ES 111th Bills, supra note 240. Exceptions included Waxman-Markey, see infra note 243, two different bills that dealt with the National Estuary Program (H.R. 4715 and 5301) (both of which passed in the House but not the Senate), a bill that would have created a scientific advisory panel to study adaptation to climate change (S.22) (which passed in the Senate but failed in the House), and the American Recovery and Reinvestment Act of 2009, which was signed in law by the President on February 17, 2009 (P.L. 111-5). C2ES 111th Bills, supra note 240 .

242 See C2ES 111th Bills, supra note 240.

243 See American Clean Energy and Security, H.R. 2454, 111th Cong. § 700 (2009) available at http://www.gpo.gov/fdsys/pkg/BחLLS-111hr2454eh/pdf/BILLS-111hr2454eh.pdf; C2ES, WaxmanMarkey Short Summary, http://www.c2es.org/federal/congress/111/acesa-short-summary (last visited July 21, 2013) [hereinafter Waxman-Markey Short Summary].

244 See H.R. $2454 \S 703$ (2009); Waxman-Markey Short Summary, supra note 243.

245 H.R. $2454 \S 321$ (2009); Waxman-Markey Short Summary, supra note 243. The Congressional Budget Office estimated that Waxman-Markey would cost American households approximately $\$ 175$ per year; EPA's estimate was between $\$ 80$ and $\$ 111$ per year. WaxmanMarkey Short Summary, supra note 243. 
Western Climate Initiative or the Regional Greenhouse Gas Initiative to exchange them for federal allowances. ${ }^{246}$

The United States House of Representatives passed Waxman-Markey by a vote of $219-212$ on June $26,2009 .{ }^{247}$ Several variations of the bill failed in the Senate, including a version supported by Senators John Kerry, Joseph Lieberman, and Lindsay Graham. ${ }^{248}$ In July 2010, however, Senate Majority Leader Harry Reid announced that any upcoming energy legislation would not include a GHG emission cap, largely ending any action on climate legislation in the 111th Congress. ${ }^{249}$

In contrast to the 111th Congress, the 112th Congress introduced "only" about 100 bills, resolutions, and amendments related to climate change. ${ }^{250}$ Similar to the legislation introduced by the 111th Congress, most of this legislation also never made it out of committee. ${ }^{251}$ Almost half of the legislation introduced in the 112th Congress actually was aimed at preventing further regulation or control of GHG emissions, including under the CAA. ${ }^{262}$ For the first time since 2003, no GHG cap and trade bill was introduced ${ }^{253}$ although at least two bills proposing a carbon tax were proposed. $^{254}$

\section{The Mandatory Greenhouse Gas Reporting Rule}

If and when Congress-or EPA under the authority of the CAAdetermines to adopt a cap-and-trade or similar market based system, EPA already has in place a verification and reporting program to provide the backbone for such a system. Relying on CAA section 114, which authorizes the Administrator to require emissions sources and other persons to provide information that the Administrator requests to carry out the $\mathrm{CAA},{ }^{255} \mathrm{EPA}$ finalized the initial Mandatory Reporting of Greenhouse Gases Rule on October 30, 2009, applicable to twenty-nine categories, including petroleum refineries, natural gas distribution facilities, natural gas liquids extraction facilities, and a number of other source categories. ${ }^{256}$ The Mandatory

246 See H.R. $2454 \S \S 321,335$; Waxman-Markey Short Summary, supra note 243.

247 Waxman-Markey Short Summary, supra note 243.

248 Ctr. For Climate and Energy Solutions, 111th Congress Climate Change Legislation, http://www.c2es.org/federal/congress/111 (last visited July 21, 2013).

249 Id.

250 Ctr. For Climate and Energy Solutions, Legislation in the 112th Congress Related to Global Climate Change, http://www.c2es.org/federal/congress/112 (last visited June 21, 2013).

251 See id.

$252 I d$.

253 Id.

254 Id. These bills included H.R. 3242, the Save our Climate Act of 2011, and H.R. 6338, the Managed Carbon Price Act of 2012. C2ES 112th Bills, supra note 240, at 3. Both bills amended the Internal Revenue Code, the first by imposing a tax on fossil fuels based on carbon content, the second by requiring a federal emission permit for the sale or use of fossil fuels or GHGs. Id.

25542 U.S.C. $\$ 7414$ (a) (2006).

256 Mandatory Reporting of Greenhouse Gases, 74 Fed. Reg. 56,260, 56,263 (Oct. 30, 2009) (codified at 40 C.F.R. $\$ \S 86,87,89,90,94,98,1033,1039,1042,1045,1048,1051,1054$, \& 1065 
Reporting Rule was extended to the remaining segments of the oil and gas industry by final rule on November $30,2010{ }^{257}$ Although EPA considered state delegation of the Mandatory Reporting Rule to remain consistent with most other CAA programs, it opted instead for a national program, notwithstanding potential overlapping reporting requirements, expressly stating its intent not to preempt state reporting programs. ${ }^{258}$

The Mandatory Reporting Rule required reporters in the first wave of covered industry categories, including refineries and power plants, to begin collecting data on January 1, 2010, with the first annual GHG reports due on March 31, 2011, for GHGs emitted or products supplied during $2010{ }^{259}$ For facilities that directly emit GHGs, reports require annual facility emissions expressed in metric tons of $\mathrm{CO}_{2} \mathrm{e}$ per year, annual GHG emissions by gas, emissions broken out at the level specified in the respective subpart, and additional data specified in the applicable subparts for each source category. ${ }^{260}$ Reports are required to be submitted electronically using EPA's Electronic GHG Reporting Tool (e-GGRT), a web-based electronic data reporting system developed by EPA. ${ }^{261}$

For parameters that could not reasonably be measured according to the monitoring and quality assurance/quality control requirements of the relevant subparts, reporters were permitted for a temporary period of time, based on the type of reporter, to use best available monitoring methods, meaning methods currently used by the facility that do not meet the specifications of a relevant subpart, supplier data, engineering calculations, or other company records. ${ }^{262}$

\section{B. Implications for the Oil and Gas Industry}

\section{Administration of the Reporting Rule}

Specific subparts of the Mandatory Reporting Rule have been adopted for both the refining and oil and gas systems industries. Subpart Y requires all petroleum refiners that distill crude oil to report on direct facility emissions. ${ }^{263}$ Depending on the unit, reporting may be required by refineries

(2012)). Interestingly, EPA stated in its October 2009 final rule that the MRR would not only inform future legislative policy decisions (such as a national carbon tax or cap-and-trade program), but would also inform decisions of EPA about whether and how to establish NSPS for source categories emitting GHGs. Id. at 56,265.

257 Mandatory Reporting of Greenhouse Gases: Petroleum and Natural Gas Systems, 75 Fed.

Reg. 74,458 (Nov. 30, 2010) (codified at 40 C.F.R. $\$ 98$ (2012)).

25874 Fed. Reg. at 56,283-84.

259 Id. at 56,379 (codified at 40 C.F.R. $\$ 98.3(\mathrm{~b})(2012)$ ).

$260 I d$. at 56,379 (codified at 40 C.F.R. $\$ 98.3($ c)(4) (2012)).

261 See generally, U.S. Envtl. Prot. Agency, Electronic Greenhouse Gas Reporting Tool, http://ghgreporting.epa.gov (last visited July 21, 2013) (uploading site for EPA Greenhouse Gas Reports).

26274 Fed. Reg. at 56,379-80 (codified at 40 C.F.R. $\$ 98.3(d)(1)$ (2012)).

263 Id. at 56,451 (codified at 40 C.F.R. $\$ 98.250-98.251$ (2012)). 
under subpart C (General Stationary Combustion Sources), subpart P (Hydrogen Production), or subpart Y (Petroleum Refineries). ${ }^{264}$ For units with certain types of continuous emissions monitors (CEMs) in place, reporters must use CEMs. ${ }^{265}$ For units without CEMs in place, reporters can elect to either install and operate CEMs or calculate emissions using methods set out in the rule. ${ }^{266}$ Engineering calculations are allowed in the final rule for reporters that do not monitor flare gas flow continuously or monitor flare heating value or carbon content at least weekly. ${ }^{267}$

The Mandatory Reporting Rule for petroleum and natural gas systems, Subpart W, was finalized on November 30, 2010, for facilities that emit GHGs of 25,000 metric tons of $\mathrm{CO}_{2} \mathrm{e}$ per year. ${ }^{268}$ Amendments were finalized on April 25, 2011, December 23, 2011, and August 24, 2012, to make technical revisions, and revisions to the definitions, reporting deadlines, and the provisions relating to the use of best available monitoring methods. ${ }^{260}$ Facilities subject to subpart $\mathrm{W}$ applicable to petroleum and natural gas systems were required to submit their first GHG reports to EPA by September 28, 2012, for 2011 emissions. ${ }^{270}$ Beginning in 2013, and each year thereafter, reports must be submitted to EPA by March 31, or the next business day in the case of a Saturday, Sunday, or holiday. ${ }^{271}$

For the onshore petroleum and natural gas production industry segment, a "facility" is defined as all emission source types on a single wellpad or associated with a single well-pad and $\mathrm{CO}_{2}$ enhanced oil recovery operations. $^{272}$ An offshore petroleum and natural gas production "facility" is defined as any platform structure affixed to offshore submerged lands and secondary platform structures connected to the primary platform

264 See id. at 56,323 tb.Y-1.

265 Id. at 56,323.

266 See, e.g., id. at 56,453 (codified at 40 C.F.R. $\S 98,253$ (c) (2012)).

267 Id. at 56,451 (codified at 40 C.F.R. $\$ \S 98.253$ (b)(1)(i) \& (ii) (2012)).

268 Mandatory Reporting of Greenhouse Gases: Petroleum and Natural Gas Systems, 75 Fed. Reg. 74,458 (Nov. 30, 2010) (codified at 40 C.F.R. $\$ 98$ (2012)). The petroleum and natural gas systems Mandatory Reporting Rule covers both offshore and onshore petroleum and natural gas production, onshore natural gas processing facilities, onshore natural gas transmission compression, underground natural gas storage, liquefied natural gas (LNG) storage, LNG import and export equipment, and natural gas distribution. 75 Fed. Reg. at 74,461-62.

269 See Mandatory Reporting of Greenhouse Gases: Petroleum and Natural Gas Systems, 76 Fed. Reg. 22,825 (Apr. 25, 2011); Mandatory Reporting of Greenhouse Gases: Petroleum and Natural Gas Systems: Revisions to Best Available Monitoring Method Provisions, 76 Fed. Reg. 59,533 (Sept. 27, 2011); Mandatory Reporting of Greenhouse Gases, 76 Fed. Reg. 73,886 (Nov. 29, 2011); Mandatory Reporting of Greenhouse Gases: Technical Revisions to the Petroleum and Natural Gas Systems Category of the Greenhouse Gas Reporting Rule, 76 Fed. Reg. 80,544 (Dec. 23, 2011); 2012 Technical Corrections, Clarifying and Other Amendments to the Greenhouse Gas Reporting Rule, and Confidentiality Determinations for Certain Data Elements of the Fluorinated Gas Source Category, 77 Fed. Reg. at 51,477 (Aug. 24, 2012).

27076 Fed. Reg. at 73,899 (codified at 40 C.F.R. $\$ 98.3(b)(1)(i v)(2012)$ ).

271 Id. (codified at 40 C.F.R. $\$ 98.3(\mathrm{~b})(1),(4)(2012)$ ).

27240 C.F.R. $\$ 98.230$ (a)(2) (2012). 
structure, ${ }^{273}$ with reporting for offshore facilities based on the Bureau of Ocean Energy Management (BOEM) regulations. ${ }^{274}$

Best available monitoring methods will only be considered by EPA for periods after 2011 for "unique or unusual circumstances which include data collection methods that do not meet safety regulations, technical infeasibility, or counter to other local, State, or Federal regulations."275 A request to use best available monitoring methods for 2013 and beyond must be submitted to EPA by September 30 of the previous year and approved by EPA. $^{276}$

\section{Lessons of the Reporting Rule}

So what have we learned to date from the Mandatory Reporting Rule as pertains to the oil and gas industry? All in all, EPA estimated that 10,000 facilities reported in 2012 for 2011, under forty-one source categories, accounting for $85 \%$ to $90 \%$ of United States GHG emissions. ${ }^{277}$ EPA states that 2011 emissions of $\mathrm{CO}_{2} \mathrm{e}$ (in million metric tons (mmt)) using reported data equaled $182 \mathrm{mmt}$ for refineries and $225 \mathrm{mmt}$ for oil and natural gas systems, compared to 2,221 mmt for electricity generation. ${ }^{278}$ EPA's GHG inventory estimates total U.S. GHG emissions in 2011 of $6,702.3 \mathrm{mmt}$ of $\mathrm{CO}_{2} \mathrm{e}{ }^{279}$ of which 1,834 mmt was from transportation, most of which is attributable to cars and trucks. ${ }^{280}$ Although reported data does not correlate exactly with estimates in EPA's GHG inventory, using reported data for rough comparison purposes, petroleum refineries and oil and natural gas systems

273 Id. $\$ 98.230(\mathrm{a})(1)$.

274 Id. $\$ 98.232(\mathrm{~b})$.

275 Mandatory Reporting of Greenhouse Gases: Petroleum and Natural Gas Systems: Revisions to Best Available Monitoring Method Provisions, 76 Fed. Reg. 59,533, 59,541 (Sept. 27, 2011) (codified at 40 C.F.R. $\$ 98.234(f)(8)(i)(2012)$ ).

276 Id. A list of the information required in the request is set forth in 40 C.F.R. $\$ 98.234$ (f)(8)(ii) (2012).

277 U.S. Envtl. Prot. Agency, greenhouse Gas Reporting Program: Subpart W PETROlEuM AND NATURAl GaS SYSTEMS - 2012 UPdATE 12 (Sept. 6, 2012), available at http:// www.epa.gov/ghgreporting/documents/pdf/2012/training/Subpart-W-update.pdf. EPA estimated 2,800 reported in the petroleum and natural gas systems industry, 145 petroleum refineries, and 128 underground coal mines. Id.

278 U.S. Envtl. Prot. Agency, GHGRP 2011: Reported Data, http://www.epa.gov/ghgreporting /ghgdata/reported/index.htmi (last visited July 21, 2013) [hereinafter 2011 Reported Data]. EPA reported that petroleum and natural gas systems ranked second, "trailing" only power plants, as to GHG emissions from facilities reporting under the Mandatory Reporting Rule. See Keith Goldberg, Oil, Gas Systems Rank 2nd in GHGs From Facilities, EPA Says, PorTFolIo MEDIA INC., http://www.law360.com/energy/articles/413325?nl_pk=553e527e-7d36-4d44-8578723a54eabdda\&utm_source=newsletter\&utm_medium=email\&utm_(last visited July 21, 2013).

279 See U.S. ENVT, Prot. AgENCY, INVENTORY of U.S. GREENHOUSE GAS EMISSIONS AND SinkS, 1990-2011, tbl. ES-2, ES-7 (Apr. 12, 2013), available at http:/www.epa.gov/climatechange /Downloads/ghgemissions/US-GHG-Inventory-2013-Main-Text.pdf [hereinafter 2011 GHG INVENTORY].

280 See id. at tbl. 2-15, 2-26 (listing the $\mathrm{CO}_{2} \mathrm{e}$ values for cars, trucks, and buses-aggregated at $1,833.7 \mathrm{mmt}$ ). 
accounted for approximately $2.7 \%$ and $3.4 \%$ of total U.S. GHG emissions, respectively, compared to $33.1 \%$ for electrical power and $27.4 \%$ for transportation (based in the case of transportation on inventory estimates) ${ }^{281}$ Accordingly, while the extraction, processing, and refining of oil and gas represents a relatively small percentage of GHG emissions in the United States, the combustion of petroleum in automobiles represents a significant source of GHG emissions.

One may then wonder how the extensive emissions of GHGs from automobile combustion might be handled if Congress ultimately adopts a market-based system. Surely consumers would not be required to account for their individual emissions from their automobiles. The GHG Reporting Rule provides a hint at how this issue might be handled. In addition to their facility emissions, Subpart MM requires suppliers of petroleum products to report the potential $\mathrm{CO}_{2} \mathrm{e}$ from the combustion or use of gasoline, other petroleum products, and natural gas liquids "used as feedstock, imported, or exported during the calendar year." 282

The implication of course is that a cap-and-trade system developed based on Mandatory Reporting Rule reporting requirements would require refineries to count and pass through to consumers both the costs of their direct GHG emissions and the costs of emissions from automobiles. An incentive-based system necessarily will result in increases in the cost of gasoline to consumers, but the costs included in the price of gasoline should be transparent to consumers and reflective of the actual emissions of the oil and gas industry. Otherwise, consumers will be made to feel that oil and gas companies are bilking them at the pump as compared to a gasoline or

281 The 2011 GHG INVENTORY, supra note 278 , represents emissions estimates in accordance with Intergovernmental Panel on Climate Change (IPCC) methodologies that do not exactly correlate with the source categories that report using the Mandatory Greenhouse Gas Reporting Tool. See id. at sec. 1.4, 1-12. Further, EPA has not taken into account all reporting data in the 2011 GHG INVENTORY, and differences are still being determined. Id. at 3-71. Accordingly, the author compared emissions data by source category from the 2011 Reported Data, supra note 278 , to estimated total emissions per the 2011 GHG INVENTORY to determine rough estimates of the percentages of total emissions by oil and gas industry category. The 2011 GHG INVENTORY reports that methane emissions from natural gas systems field production actually decreased by $12 \%$ from $1990-2011, i d$. at 3-60, but additional studies on methane emissions are being performed that EPA intends to take into account in its inventory estimates. Id. at 3-70. Some commentators have also suggested that methane emissions from completions and workovers with hydraulic fracturing are underestimated in the inventory. Id at 371 . In fact, the EPA inspector general recently issued a report that EPA has a poor understanding of emissions from the oil and natural gas production segment. U.S. ENvTL. PROT. AGENCY, OfFICE OF INSPECTOR Gen., EPA NeEds to ImProve Air Emissions Data for the Oil and Natural Gas Production SECTOR 20 (2013), available at http://www.epa.gov/oig/reports/2013/20130220-13-P-0161.pdf.

282 Mandatory Reporting of Greenhouse Gases, 74 Fed. Reg. at 56,260, 56,491 (Oct. 30, 2009) (codified at 40 C.F.R. $\S 98.392$ (2012)). In the case of importers, reporting is subject to a de minimis exception if annual imports or annual exports are less than 25,000 metric tons $\mathrm{CO}_{2} \mathrm{e}$ per year. Id. at 56,377 (codified at 40 C.F.R. $\$ 98.2$ (a)(4)(ii) (2012)). In addition, refineries are permitted under the rule to subtract the emissions from intermediate products that enter the refinery to be further refined or used on site in calculating emissions that would result from combustion or use. Id. at 56,491 (codified at 40 C.F.R. $\$ 98.393$ (2012)). 
consumption tax imposed directly on consumers related to their own automobile emissions.

Further, while the reporting requirements now are used only for informational purposes, those requirements take on new meaning when attached to actual financial implications of a cap-and-trade system. For example, each report under the Mandatory Reporting Rule must be certified, signed, and submitted by "one, and only one" designated representative of the facility under penalty of law that the designated representative has personally examined the report and that the information contained in the report is, to the best knowledge of the designated representative, true, accurate, and complete. ${ }^{283}$ The designated representative also must certify that he or she is aware of the fines or imprisonment that may be imposed for false statements or omissions of required information. ${ }^{284}$

A "true, accurate, and complete" certification may be unreasonable given the significant engineering estimates and judgments that must be used to calculate GHG emissions, subjecting plant managers to unreasonable potential criminal liability for incorrect reports. Reports will be much more highly scrutinized if attached to emissions limits and tradable allowances.

\section{STATE MARKET BASED REgUlatToN OF GHG}

\section{A. California Cap and Trade}

California officially launched its cap-and-trade program (the California Program) on November 14, 2012, with the first auction of allowances for GHG emissions. ${ }^{285}$ Effective on January 1, 2012, the California Program "establishes a system of market-based declining annual aggregate emissions limits for sources or categories of sources that emit greenhouse gas emissions." 286 According to the California Air Resources Board (the ARB), the California Program is applicable to about 350 businesses, representing 600 facilities. $^{287}$ Although the inaugural cap-and-trade auction is only one of many measures California has taken over the past three decades to attempt

283 Id. at 56,381-82 (codified at 40 C.F.R. $\S 98.4(\mathrm{e})(1)(2012)$ ).

284 Id.

285 Jason Dearen, California Debuts Landmark Program To Cap Emissions, AssocIATED PRESS Nov. 14, 2012, http://bigstory.ap.org/article/california-debut-landmark-cap-and-tradesystem (last visited July 21, 2013). Dearen quotes Severin Borenstein, Professor at the University of California, Berkeley, as stating: "Cap and trade is still probably the most likely way we eventually could get to a national carbon mitigation program." He also cites Shelly Sullivan of the AB 32 Implementation,Group, a business coalition that favors greenhouse gas reductions but opposes the auctioning of allowances: "Raising costs in California will allow out-of-state firms to lower prices and take market share[.]"

286 CAL. HEALTH \& SAFETY CODE \$38562(c) (West 2013).

287 Cal. Envtl. Prot. Agency, Air Resources Board, Overview of ARB Emissions Trading Program, Oct. 20, 2011 available at http://www.arb.ca.gov/newsrel/2011/cap_ trade_overview.pdf [hereinafter ARB]. 
to combat climate change, ${ }^{288}$ it arguably has the most potential of any existing state programs to change the way the United States deals with GHGs and climate change in general. ${ }^{289}$

The basic idea of the California Program is simple: to reduce GHG emissions to 1990 levels by $2020,{ }^{230}$ take an enforceable emissions cap that declines over time, and distribute allowances equal to emissions allowed under the cap. ${ }^{201} \mathrm{An}$ allowance is a "tradable permit to emit one metric ton of a carbon dioxide equivalent greenhouse gas emission." ${ }^{202}$ An offset is "equivalent to a GHG reduction or GHG removal enhancement of one metric ton $\mathrm{CO}_{2} \mathrm{e} .{ }^{\text {,203 }}$ Facilities covered by the program surrender a number of "allowances and offsets equal to their emissions at the end of each compliance period. ${ }^{2294}$

The Program allocates "free allowances" to industrial sectors equal to about $90 \%$ of the sector's average emissions, but the number of these free allowances decreases over time. ${ }^{206}$ Trading and banking of allowances is allowed, and the ARB will hold quarterly auctions and reserve sales of

288 As far back as 1988, California had begun to take action on GHGs and climate change. Passed in 1988, Assembly. Bill 4420 directed the California Energy Commission to prepare and maintain an inventory of GHGs. See Cal. Energy Comm'n, California Energy Commission's Climate Change Activities, http://www.energy.ca.gov/climatechange/ (last visited July 21, 2013) ("The Energy Commission was also statutorily directed to prepare and maintain the state's inventory of Greenhouse Gas (GHG) emissions."). California began moving toward its current cap-and-trade program with Governor Schwarzenegger's Executive Order S-3-05. See CAL. ENVTL. PROT. AGENCY, CLIMATE ACTION TEAM REPORT TO GOVERNOR SCHWARzENEGger AND THE LEGISLATURE 5 (2006) available at http:/www.climatechange.ca.gov/climate_action_team/ reports/2006report/2006-04-03_FINAL_CAT_REPORT.PDF (stating that the Executive Order "established climate change emission reduction targets for the state and set in motion a process to ensure the targets [were] met."). In response to the Executive Order, the Secretary of the California Environmental Protection Agency (CalEPA) created a Climate Action Team to recommend climate change emissions reduction strategies. Id. at 19 . At the time the Climate Action Team issued its first report to the Governor and the Legislature in March 2006, the Team's major and yet unimplemented recommendation was the creation of a market-based program, which the team called an "integral part" of reducing climate change emissions. Id. at 100.

289 The Regional Greenhouse Gas Initiative (RGGI), currently consisting of Connecticut, Delaware, Maine, New Hampshire, New York, Vermont, Massachusetts, Rhode Island, and Maryland, was the "nation's first mandatory, market-based program to reduce emissions of carbon dioxide $\left(\mathrm{CO}_{2}\right)$," but focuses exclusively on emissions of $\mathrm{CO}_{2}$ from fossil fuel-fired power plants. See RGGI, FACT SheEt: AbOUT THE REgional Greenhouse Gas Initiattve (RGGI) 1

(2012) available athttp://www.rggi.org/docs/Documents/RGGI_Fact_Sheet_2012_09_28.pdf.

290 CAL. HEALTH \& SAFETY CODE $\$ 38550$ (West 2013).

291 Cal. Envtl. Prot. Agency, ARB, Assembly Bill 32: Global Warming Solutions Act, http://www.arb.ca.gov/cc/ab32/ab32.htm (last visited July 21, 2013) [hereinafter ARB, AB 32 Summary].

292 CAL. Envtl. Prot. Agency, ARB, CAP-AND-Trade Regulation Instructional Guidance 12 (2012), available at http://www.arb.ca.gov/cc/capandtrade/guidance/chapterl.pdf\#page=2 [hereinafter ARB, INSTRUCTIONAL GUIDANCE]; see CAL. CODE REGS. $17 \S 95820$ (West 2013).

293 ARB, INSTRUCTIONAL GUIDANCE, supra note 292 at 12; see CAL. CODE REgS $17 \S 95870$ (West 2013).

294 ARB, AB 32 Summary, supra note 291; see CAL. CODE REGS. $17 \S 95856$ (West 2013).

295 ARB, INSTRUCTIONAL GUIDANCE, supra note 292, at 15-16. 
allowances. ${ }^{298}$ Offsets are allowed for up to $8 \%$ of a facility's compliance obligation and are limited to projects that create emission reductions in four areas: forestry, urban forestry, dairy digesters, and destruction of ozonedepleting substances. ${ }^{207}$ Every year, entities must surrender allowances and offsets for $30 \%$ of the prior year's emissions. Every third year, entities must surrender allowances and offsets for the remainder of the entity's emissions in that three-year compliance period. ${ }^{208}$ The penalty for missing the program's requirements is severe: four allowances must be provided for every one allowance that was not timely surrendered. ${ }^{200}$

\section{B. Implications for the Oil and Gas Industry}

Oil and gas operators are required to comply with the California Program if they are a "Covered Entity" that meets the inclusion thresholds. ${ }^{300}$ An entity is a "Covered Entity" if it is an operator of a facility within California that has one or more processes or operations that fall into certain categories, including petroleum and natural gas systems, petroleum refining, and suppliers of natural gas. ${ }^{301}$ The inclusion thresholds for most Covered Entities, including petroleum and natural gas facilities and carbon dioxide suppliers, is 25,000 metric tons or more of $\mathrm{CO}_{2}$ equivalent per data year. ${ }^{302}$ For purposes of calculating whether an entity meets the inclusion threshold and the entity's compliance obligations, the ARB will look to reports submitted under California's Mandatory Reporting Regulation created pursuant to Assembly Bill 32 (AB 32), ${ }^{303}$ the legislation setting California's GHG reduction strategy into law. ${ }^{304}$

296 Reserve sales are sales of allowances that are conducted on the first business day six weeks after each quarterly allowance auction. CAL. CODE REGS. 17 § 95913(d)(2) (West 2013). The first reserve sale is to be conducted on March 8, 2013. Id. $\S 95913(d)(1)$. Reserve sales are only open to covered entities and opt-in covered entities; they are not open to speculators. Id \& 95913(c). The allowances at reserve sales come from the "Allowance Price Containment Reserve." Id. § 95913(a). The Allowance Price Containment Reserve will contain 1\% of the allowances from budget years 2013-2014, 4\% of the allowances from budget years 2015-2017, and $7 \%$ of the allowances from budget years 2018-2020. Id. $\S 95870$ (a). There is no "reserve" or minimum price at reserve sales. Allowances for 2013 reserve sales will be sold in three price tiers: $\$ 40, \$ 45$, and $\$ 50$. Id. $\S 95813(\mathrm{e})(3)$. Price tiers increase after 2013. Id. $\S 95913(\mathrm{e})(4)$.

297 See id. $\S 95873(\mathrm{a})(2)(\mathrm{C})$; CAL. ENVTL. PROT. Agency, ARB, OVERview of ARB Emissions TRADING PROGRAM (2011), available at $\mathrm{http}: / \mathrm{w} w \mathrm{w}$.arb.ca.gov/newsrel/2011/cap_trade_ overview.pdf [hereinafter ARB, Trading PRogram OvERVIEw].

298 Cal. Code Regs. $17 \S \S 95853$, 95855 (West 2013); ARB, Trading Program Overview, supra note 297.

299 See Cal. Code Regs. $17 \S 95857$ (West 2013); ARB, Trading Program Overview, supra note 297 .

300 CAL. CODE REGS. $17 \S \S 95811,95812$ (West 2013).

301 Id. $\S 95811$.

302 Id. $\S 95812(\mathrm{c})(1),(\mathrm{c})(3)-(4)$.

303 The California Global Warming Solutions Act of 2006, ch. 488, 2006 Cal. Stat. 3419 (codified at CAL. HEALTH \& SAFETY CODE $\S 38500$ et seq. (West Supp. 2013)) [hereinafter AB 32], is the 2006 legislation that put many of California's GHG reduction strategies, including the California Program, into motion. For a brief overview of the requirements of $A B 32$, see Cal. 
Not all oil and gas companies are required to comply with the California Program immediately. Compliance with the program is enforceable beginning in 2012 for electric utilities and what the ARB characterizes as "large stationary sources." ${ }^{\text {"O5 }}$ Such large sources include refineries and oil and gas production facilities. ${ }^{306}$ Compliance is enforceable beginning in 2015 for suppliers of natural gas, distillate fuel oil, and liquefied petroleum gas. ${ }^{307}$

How the program will work over time, the financial impacts it will have on the oil and gas industry, and whether it will survive oncoming litigation is just beginning to play out. At the ARB's first quarterly auction on November 14,2012 , the ARB sold all of the more than 23 million 2013 vintage $^{308}$ allowances offered for sale for a price of $\$ 10.09$ per ton, but only 5.6 million of the 39.5 million offered 2015 vintage allowances, for a price of $\$ 10.00$ per ton. $^{309}$ The reserve-or minimum-price for both 2013 and 2015 allowances also was $\$ 10.00$ per ton. ${ }^{310}$

While the ARB called the first auction a success, ${ }^{311}$ not everyone who followed the process agreed. ${ }^{312}$ At just nine cents above the minimum price

Envtl. Prot. Agency, ARB., Assembly Bill 32: Global Warming Solutions Act, http://www.arb.ca.gov/cc/ab32/ab32.htm (last visited July 21, 2013).

304 CAL. CODE REGS. $17 \S \S 95850,95852$ (West 2013). Note, however, that certain categories of emissions count toward inclusion thresholds, but do not count toward an entity's compliance obligation. Id. $\$ 95852.2$. Exempt emissions include $\mathrm{CO}_{2}$ emissions from "biomass-derived fuels" and process, "vented, and fugitive emissions" from: "geothermal generating units and geothermal units and facilities... natural gas hydrogen fuel cells ... storage tanks used in petroleum and natural gas production and natural gas transmission . . natural gas transmission storage tanks used in petroleum and natural gas production and natural gas transmission, and from produced water ... [and] petroleum refineries[,] [ ] asphalt blowing operations, equipment leaks, storage tanks, and loading operations[.] Id. $\S \S 95852.2(\mathrm{a}),(\mathrm{b})(1)-(3),(\mathrm{b})(5)-(6)$. The ARB is currently "developing two GHG and VOC testing procedures [that would] quantify fugitive emissions" associated with the oil and gas industry. Cal. Envtl. Prot. Agency, ARB., Oil and Natural Gas Production, Processing, and Storage, http:/www.arb.ca.gov/cc/oil-gas/oil-gas.htm (last visited July 21, 2013).

305 CAL. CoDE REgS. $17 \S \S 95850,95852(a)-(b)$ (West 2013); ARB, INSTRUCTIONAL GuIdANCE, supra note 292 , at 13 .

306 ARB, InStRuctional Guidance, supra note 292, at 13; CAL. CODE REgS. 17 95851(a) (West 2013).

307 CAL. COdE REgs. $17 \S$ 95851(b) (West 2013); ARB, InSTRUCTIONAL GuIDANCE, supra note 292 , at 22 .

308 "The vintage of an allowance determines the year in which it may be first used for compliance." Press Release, Cal. Envtl. Prot. Agency, Air Review Bd., Air Resource Board Posts Notice for California's First Cap-and-Trade Auction (Sept. 14, 2012), available at http://www.arb.ca.gov/newsrel/newsrelease.php?id=351.

309 Cal. Envtl. Prot. Agency, Air Res. Bd., California Air Resources Board Quarterly AUCTION 1, available at $\mathrm{http} / /$ www.arb.ca.gov/cc/capandtrade/auction/november_2012/auction

1_results_2012q4nov.pdf.

310 Id.

311 Cal. Envtl. Prot. Agency, Statement by Air Resources Board Chairman Mary D. Nichols on California's first cap-and-trade auction, Nov. 19, 2012, http://www.arb.ca.gov/newsrel/news release.php?id=367 (last visited July 21, 2013) (quoting California Air Resources Board Chairman Mary D. Nichols: "The auction was a success and an important milestone for California as a leader in the global clean tech market. By putting a price on carbon, we can break our unhealthy dependence on fossil fuels and move at full speed toward a clean energy 
and anywhere from ninety cents to $\$ 4.00$ below initial estimates, ${ }^{313}$ the going rate appeared to support the arguments of some environmental groups that cap-and-trade will simply allow bigger companies to buy up significant numbers of credits and maintain their current rate of emissions. ${ }^{314}$ Others maintained that the system will work in time. ${ }^{315}$ Still others suggested that the relatively low price as compared to the minimum price may have been influenced by ongoing litigation that threatens to halt the program and the fact that almost no speculators participated in the first auction. ${ }^{316}$

Since that first auction, the price of allowances has increased somewhat. At the second auction, held on February 19, 2013, the ARB sold another 12.9 million 2013 vintage allowances for $\$ 13.62$ per ton, and 4.4 million 2016 vintage allowances for $\$ 10.71$ per ton, a price which equaled the floor price. ${ }^{317}$ At the third auction, on May 16, 2013, 14.5 million additional 2013 vintage allowance were sold for $\$ 14.00$ per ton, while 9.6 million more 2016 vintage allowances were sold, once again for the floor price of $\$ 10.71$ per ton. ${ }^{318}$

Environmental groups have argued these results indicate a strong carbon market, while also raising money to reduce carbon pollution in California. ${ }^{319}$ Yet California Governor Jerry Brown has already tapped $\$ 500$ million in 2013 auction proceeds to balance the state's budget, a "loan" that

future. That means new jobs, cleaner water and air-and a working model for other states, and the nation, to use as we gear up to fight climate change and make our economy more competitive and resilient."); see also Envtl. Def. Fund, Results From California's First Cap-andTrade Auction Indicate Strong Market, http:/www.edf.org/news/results-california\%E2\%80\%99sfirst-cap-and-trade-auction-indicate-strong-market (last visited July 21, 2013).

312 See Barbara Grady, With California Carbon Cap-and-Trade Program Launch, Experts Debate Economic Side Effects, SAN Francisco PUBLIC Press, Nov. 15, 2012, http://sfpublicpress.org/news/2012-11/with-california-carbon-cap-and-trade-program-launchexperts-debate-possible-economic-side-effe (last visited July 21, 2013).

313 Ricardo Lopez, California's First Carbon-Credit Auction Raises $\$ 290$ Million, L.A. TIMES, Nov. 20, 2012, http://www.latimes.com/business/la-fi-pollution-credits-20121120,0,1417750.story (last visited July 21, 2013).

314 See Felicity Barringer, California's $\mathrm{CO}_{2}$ Now Has a Price, But a Low One, N.Y. TImes, Nov. 20, 2012, http:/green.blogs.nytimes.com/2012/11/20/califomias-co2-now-has-a-price-but-a-lowone/ (last visited July 21, 2013); Grady, supra note 312. See also Andrea Donsky, Hansen Was Right: Cap and Trade Isn't the Solution, TREeHUGGer, December 7, 2009, http://www.treehugger.com/corporate-responsibility/hansen-was-right-cap-and-trade-isnt-thesolution.html (last visited July 21, 2013).

315 See Barringer, supra note 314.

316 See id.

317 Cal. Env. Prot. Agency, AIr Res. Bd., CALIFornia AIr Resources BoARd Quarterly AUCTION2, FEBRUARY 2013 (2013), available athttp:/www.arb.ca.gov/cc/capandtrade/auction /february_2013/updated_feb_results.pdf.

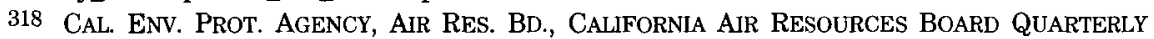
AUCTION 3, MAY 2013 (2013), available at http://www.arb.ca.gov/cc/capandtrade/auction/may2013/results.pdf.

319 See, e.g., Emily Reyna, Envtl. Def. Fund, Results From California's Cap and Trade Program: California's Cap and Trade Program After Six Months: Three Reasons the Momentum is Here to Stay, available at http;//blogs.edf.org/californiadream/2013/05/21/californias-cap-andtrade-program-after-six-months-three-reasons-the-momentum-is-here-to-stay/. 
Governor Jerry Brown has said will be repaid. ${ }^{320}$ These actions appear to support the litigation claims brought in separate suits by the California Chamber of Commerce ${ }^{321}$ and the Pacific Legal Foundation ${ }^{322}$ that the ARB program constitutes an unconstitutional tax because revenues massively exceed what is required to administer the program. Assuming the program survives these claims and the price of carbon increases over time as predicted, so will the price to operate in California. Whether Californians accept or reject the related increase in energy prices will be a telling predictor of the potential for a federal market-based system.

\section{CONCLUSION}

Interwoven with complex issues of national energy supply, national security implications, and the professed role of fossil-fuel emissions in heating up the planet, climate change can be an emotional issue. ${ }^{323}$ But despite the projected rise in U.S. oil and gas production and the characterization of the coal and oil and gas industries as the root causes of climate change, President Obama's path forward was unclear after his second term election. ${ }^{324}$ The Administration did not seek a carbon tax as part of a package to avoid the so-called fiscal cliff, ${ }^{325}$ agreed to very little at the

320 See Editorial, California's Cap-and-Tax Grab, WALL ST. J. (June 17, 2013), at A18.

321 Verified Petition for Writ of Mandate and Complaint for Declaratory Relief, at 4, Cal. Chamber of Commerce v. Cal. Air Res. Bd., No 2012-800001313 (Cal. Super Ct., Nov. 13, 2012), available at $\mathrm{http} / / \mathrm{www}$.calchamber.com/GovernmentRelations/Documents/FILED_Petition_1113-12.pdf.

322 Verified Petition for Writ of Mandate and Complaint for Declaratory Relief, at 2, Morning Star Packing Co. v. Calif. Air Res. Bd., No. 2013-800001464 (Cal. Super Ct., Apr. 16, 2013), available at $\mathrm{http}: / / \mathrm{www}$.pacificlegal.org/document.doc?id=836.

323 See Yvonne Wingett Sanchez, Gov. Jan Brewer Chides Reporter Over Question, ARIz. REPUBLIC, Dec. 6, 2012, http://www.azcentral.com/news/politics/articles/20121206gov-janbrewer-chides-reporter-over-question.html?nclick_check=1 (last visited July 21, 2013) (describing how Arizona Governor Jan Brewer hit a reporter after he asked her about global warming); Andrew Paxton, Climate Change Debate Heats Up, http://aztecpress online.com/2013/03/climate-change-debate-heats-up/ (last visited July 21, 2013).

324 John McArdle, Time's Not Ripe For Major New Push On Global Warming-Obama, E\&E PuBlishing, LLC, Nov. 14, 2012, http://eenews.net/eenewspm/2012/11/14/archive/1?terms= time\%27s+not+ripe (last visited July 21, 2013) (quoting President Barack Obama as stating in his first news conference after winning reelection that he has more pressing items on his agenda, including the economy, jobs, and growth, than climate change); Nick Juliano \& John McArdle, Status Quo Results Mean Recent Battles Will Be Revisited and Gridlock May Reign, E\&E PUBLISHING, LLC, Nov. 7, 2012, http://www.eenews.net/eedaily/stories/1059972171 (last visited July 21, 2013) (noting that, in his acceptance speech, President Obama talked of passing on a country that "isn't threatened by the destructive power of a warming planet.").

325 Jean Chemnick, Obama Will Not Propose Carbon Tax in Fiscal Negotiations - Treasury Official, E\&E PUBLISHING, LLC, Nov. 13, 2012, http://www.eenews.net/eenewspm/2012/11/13 /archive/1?terms=Obama+will+not+propose + carbon+tax + in + fiscal + negotiations (last visited July 21, 2013) ("The Obama Administration "has not proposed a carbon tax, nor is it planning to'...."). 
annual 2012 United Nations Climate Conference in DOHA, Qatar, ${ }^{326}$ and shifted its focus in early 2013 toward other priorities, including gun control initiatives in the wake of the tragic shootings at Sandy Hook Elementary School. ${ }^{327}$

The approach of the Administration, however, has become more evident since the President's 2013 State of the Union address, when he urged Congress to pass a cap-and-trade bill, but then stated: "[i]f Congress won't act soon to protect future generations, I will. ${ }^{\text {328 }}$ President Obama has now made specific pledges through his Climate Action Plan to move forward on GHG emission controls, leaving Congress behind, and relying on EPA to creatively craft regulations under ill-fitting provisions of the CAA. ${ }^{329}$

Although some Democratic legislators believe that if a regulatory action is onerous enough that Republicans could be forced into a climate change compromise, ${ }^{330}$ a legislative solution is extremely unlikely. ${ }^{331}$ So long as the Senate is controlled by Democrats and the House by Republicans, legislative attempts to either block EPA authority or derail the growing regulatory burden, or to pass a cap-and-trade system or carbon tax, will certainly fail. ${ }^{332}$ In fact, the political divide between Democrats and Republicans appears to be widening. ${ }^{333}$ Although Environmental groups and progressive think tanks

326 See Jean Chemnick, Debate Begins Anew - Do U.N. Talks Matter in Washington?, E\&E PUBLISHING, LLC, Dec. 10, 2012, http://www.eenews.net/Greenwire/2012/12/10/archive/1?terms= debate+begins+anew (last visited July 21, 2013).

327 Shortly after the shootings on December 14, 2012, President Obama announced that he had asked Vice President Biden to create a proposal for legislation aimed at reducing gun violence. See The White House, Now Is The Time To Do Something About Gun Violence, www.whitehouse.gov/issues/preventing-gun-violence (last visited July 21, 2013). Vice President Biden delivered his recommendations on Jan. 15, 2013. Id.

328 State of the Union 2013: President Obama's Address to Congress (Transcript), WaSH. POST, Feb. 12, 2013, http://articles.washingtonpost.com/2013-02-12/politics/37059380_1_applause -task-free-enterprise (last visited July 21, 2013).

329 See generally, ClIMATE ACTION PLAN, supra note 183; While Congress Sleeps, THE ECONOMIST (June 29, 2013).

330 See Jean Chemnick, Obama Unges Congressional Action in State of the Union - But Might Take Matters Into His Own Hands, E\&E PuBlishing, LLC, Feb. 13, 2013, http://www.eenews.net/EEDaily/2013/02/13/archive/1?terms=Obama+urges+congressional+acti on (last visited July 21, 2013). Rep. John Shimkus (R-Ill.) responded that Republicans would move to block excessive regulation. Id.

331 Id.

332 On March 12, 2013, Senator Sheldon Whitehouse, Representative Henry Waxman, Representative Earl Blumenauer, and Senator Brian Schatz, released a discussion draft to stakeholders of a carbon tax bill. See Press Release, Sheldon Whitehouse, Waxman, Whitehouse, Blumenauer, and Schatz Release Carbon Price Discussion Draft (Mar. 12, 2013), available at $\mathrm{http}$ ://democrats.energycommerce.house.gov/index.php?q=news/waxman-white house-blumenauer-and-schatz-release-carbon-price-discussion-draft. Leaving little time for discussion of the discussion draft, two days later, on March 14, 2013, Representative Steve Scalise sponsored a House Resolution that states "that it is the sense of Congress that a carbon tax would be detrimental to American families and businesses, and is not in the best interest of the United States." H.R. Con. Res. 24, 113th Cong. (2013).

333 See Jean Chemnick, DIM GOP ENTHUSIASM FOR CAP-AND-TRADE BILL IN 2009 EVEN DIMMER Now, E\&E PUBLISHING, LLC, June 4, 2013, http://www.eenews,net/eedaily/stories/1059982203 
cannot bring legal action against Congress for the failure to legislate; they can and will continue to pursue EPA to adopt new GHG regulations under the $\mathrm{CAA}^{334}$

One could argue that EPA's regulatory efforts may actually benefit the natural gas industry. Amidst reports that use of natural gas for electricity has lowered U.S. $\mathrm{CO}_{2}$ emissions to levels not seen for eighteen years, ${ }^{335}$ the Administration's current stance seemingly favors natural gas. ${ }^{336}$ Despite appearances, however, the Administration still faces a quandary whether to continue its preference for natural gas in its power plant NSPS, a position favored by many environmentalists (except of course those that oppose all drilling and hydraulic fracturing), but intractably opposed by portions of the county with economies that rely on coal. ${ }^{337}$ These choices are further complicated by the potential price implications of increased LNG exports, and whether the coal the U.S would otherwise burn should be exported to foreign nations. ${ }^{335}$

Any respite enjoyed by the oil and gas industry from additional GHG regulation in the short-term will quickly expire once the terms of the power plant NSPS are finally resolved. EPA then will turn its attention to methane and other GHG-specific performance standards for oil and natural gas systems and refineries and likely tighten standards for permitting and the use of best available control technology under the Prevention of Significant Deterioration program. The oil and gas industry should thus brace itself for ever-tighter command and control GHG regulations ${ }^{339}$ under the CAA, together with the associated compliance costs, operating costs, consumer price increases, and lawsuits.

(last visited July 21, 2013) (proposing that Republican lawmakers are more focused on primary elections and fearful of deviating from party platform).

334 For example, The Institute for Policy Integrity, a think tank at the New York University School of Law, filed a notice on November 28, 2012, that it intends to sue EPA if the agency fails to consider a new cap and trade program for vehicle greenhouse gas emissions. Inst. for Pol'y Integrity, Project Update: File Notice of Intent to Sue EPA, http://policyintegrity.org/what-wedo/update/file-notice-of-intent-to-sue-epal/ (last visited July 21, 2013).

335 U.S. ENERGY INFO. ADMIN., ENERGY-RELATED CARBON DIOXIDE EMISSIONS DECLINED IN 2012 (2013), available at http:/www.eia.gov/todayinenergy/detail.cfm?id=10691.

336 See Begos, supra note 209; Matthew Daly, Moniz Backs Natural Gas 'Revolution,' ASSOCIATED PRESS, Apr. 9, 2013, http://bigstory.ap.org/article/moniz-backs-natural-gas-revolution (last visited July 21, 2013).

337 See Trip Gabriel, G.O.P. Sees Opportunity for Election Gains in Obama's Climate Change Policy, N.Y TIMES, July 1, 2013, at Al0.

338 See Keith Johnson, U.S. Coal Finds Warm Embrace Overseas, WALL ST. J. Feb. 6, 2013, at $\mathrm{B1}$, available at $\mathrm{http} / / /$ online.wsj.com/article/SB100014241278873236449045782718305639799 20.html ("Last year, the U.S. set a record for coal exports, with the final tally estimated to top 120 million tons, double what it exported as recently as $2009 . ")$.

339 Some environmental interests argue that command-and-control regulation is more effective at climate change mitigation that market-based systems and that costs should not be a consideration anyway, making the Clean Air Act the perfect tool of EPA. See, e.g., Holly Doremus \& W. Michael Hanemann, Of Babies and Bathwater: Why the Clean Air Act's Cooperative Federalism Framework is Useful for Addressing Global Warming, 50 ARIZ. L. REV. $799,800,822$ (2008). 